\title{
Running gears of sets of freight wagons coupled with diesel or electric traction vehicle
}

\section{Układy biegowe zespołów wagonów towarowych sprzęgniętych z pojazdem trakcyjnym spalinowym lub elektrycznym}

\begin{abstract}
The article presents a review of the constructional solutions of running gears of freight wagons resulting from the requirements of national and European regulations. A short characteristic of traction vehicles operating in freight traction is presented. The main types of bogies used in Poland and Europe, mainly the family of bogies of Y25 type, are described. A brief historical overview of the running systems of freight wagons is provided. A brief historical outline of the running gears of freight wagons is contained. Requirements of the interchangeability of the running gear as a standard gear are presented. The main issues related to the design of running gears, requirements, criteria, technical specifications are discussed.

$W$ artykule przedstawiono przeglad rozwiqzań konstrukcyjnych układów biegowych wagonów towarowych wynikajacych z wymagań zawartych $w$ krajowych jak $i$ europejskich przepisach. Przedstawiono krótka charakterystykę pojazdów trakcyjnych poruszajacych się $w$ trakcji towarowej. Opisano główne typy wózków stosowanych w Polsce i Europie przede wszystkim rodzinę wózków typu Y25. Zawarto krótki rys historyczny układów biegowych wagonów towarowych. Przedstawiono wymagania zamienności uktadu biegowego jako układu standardowego. Omówiono główne zagadnienia zwiqzane $z$ projektowaniem układów biegowych, wymaganiami, kryteriami, specyfikacja techniczna.
\end{abstract}

Keywords: running gear, freight traction, standard running gear, Y25, requirements for running gear,

Stowa kluczowe: uklad biegowy, trakcja towarowa, układ biegowy standardowy, Y25, wymagania dla uktadów biegowych,

\section{INTRODUCTION}

Transport is called the transport of people or goods from point $\mathrm{A}$ to point $\mathrm{B}$. Due to the widely developed network of worldwide supplies, currently transport plays a crucial role for the world economy, as it affects the supplies of products for industry, services and directly to households.

The water transport, land transport (railway and road), air and special (e.g. pipeline) are included within the most important branches of transport. Currently, actions concerning limitation of negative impact of mentioned sectors on the environment are being taken all over the world. Currently, work is in progress to develop the solutions enabling the non-invasive assessment of ecological indicators of moving vehicles.

The rail transport of goods is carried out with using the freight wagons coupled with at least one active locomotive (diesel or electric), appropriately marked, having the authorized documents appropriate for the given transport, marked with a number and having a timetable.

We distinguish the following types of trains [9]:

\section{WPROWADZENIE}

Transportem nazywamy przewóz osób lub towarów z punktu A do punktu $\mathrm{B}$. Ze względu na mocno rozbudowaną sieć ogólnoświatowych dostaw, obecnie transport pełni newralgiczną rolę dla światowej gospodarki, gdyż ma wpływ na dostawy produktów dla przemysłu, usług oraz bezpośrednio do gospodarstw domowych.

Do najważniejszych gałęzi transportu zaliczamy: transport wodny, lądowy (kolejowy i drogowy), powietrzny i specjalny (np. rurociagowy). Obecnie na całym świecie podejmuje się działania dotyczące ograniczania negatywnego wpływu wymienionych sektorów na środowisko naturalne. Obecnie trwają prace nad opracowaniem rozwiązań umożliwiających bezinwazyjną ocenę wskaźników ekologicznych poruszających się pojazdów.

Transport szynowy towarów odbywa się przy wykorzystaniu wagonów towarowych sprzęgniętych z co najmniej jedną czynną lokomotywą (spalinową lub elektryczna), odpowiednio oznakowany, posiadający właściwe dla danego przewozu dokumenty dopuszczające, oznaczony numerem i posiadający rozkład jazdy. 
- direct freight trains - they consist of the same type of freight wagons and are intended for transport of homogeneous type of cargo in mass quantities. Generally, they are the shuttle trains, the essence of which consists in moving of a compact set of freight wagons with cargo in one direction and empty wagons on the return journey. Between the transport of goods, there are - at turning points - loading and unloading operations.

- $\quad$ group freight trains - they can be composed of the same type of freight wagons or different types of freight wagons, but grouped according to the destination to which the given group of wagons will be directed. There may be from two to several wagon groups in a freight train. This type of freight train provides service of several destinations of cargo, especially when the part of the transport route of the individual groups of wagons - from the point of shipment to the point of destination - is the same. During the transport, at an optimal point for this purpose, the group freight train is divided and the wagon groups are directed to the individual destinations as the newly formed freight trains.

- intermodal freight train - composed of freight wagons intended for the transport of loading units (such as containers, semitrailers or whole trucks).

- transfer and collective trains - intended to service the loading points belonging to the service area of a given marshalling yard. Their purpose is to deliver wagons to these points (loaded and ordered empty for loading) and to collect wagons (after unloading or loaded). After delivery to the marshalling yard, the wagons are formed into the new trains and directed on their way.

Section trains - intended to transport services between marshalling yards. Among this type of trains the longdistance freight trains can be distinguished, the route of which passes through at least one marshalling yard.

As mentioned above, a diesel locomotive is very often used as a power source in freight trains - due to the still insufficient electrification of railway lines in Poland. Currently the existing locomotives can be divided into two types:

- shunting - very often bidirectional, enabling safe and quick work related to shunt the goods. Locomotives of this type have a significantly different character of work compared to locomotives used in passenger and freight traffic. A large percentage of the work is done by the engine at idle and small loaded. The nature of the cargo is one of the reasons of high fuel consumption [3].

- for tractive work - having much more power than shunting ones and moving at higher speeds.

A diesel locomotive is distinguished by definite specificity, which enables its trouble-free use and increases the scope of activities. The tare weight index of diesel tractive locomotives, related to the power at the circumference of the driving wheels, remains at the level of $50-60 \mathrm{~kg} / \mathrm{kW}$, and the unit mass of the drive
Rozróżniamy następujące typy pociągów [9]:

pociagi towarowe bezpośrednie - składają się $\mathrm{z}$ tego samego rodzaju wagonów towarowych i przeznaczone są do przewozu jednorodnego rodzaju ładunku w masowych ilościach. Zasadniczo są to pociagi towarowe wahadłowe, których istota przewozu polega na przemieszczaniu się zwartego składu wagonów towarowych $\mathrm{z}$ ładunkiem $\mathrm{w}$ jednym kierunku i wagonów próżnych w drodze powrotnej. Pomiędzy przewozem ładunków następują - w punktach zwrotnych - operacje załadunku i rozładunku.

- pociagi towarowe grupowe - zestawione mogą być $\mathrm{z}$ tego samego rodzaju wagonów towarowych albo różnych rodzajów wagonów towarowych, ale zgrupowanych według miejsc przeznaczenia, do jakiego dana grupa wagonów będzie kierowana. Może być od dwóch do kilku grup wagonowych w pociagu towarowym. Ten typ pociagu towarowego umożliwia obsługę kilku punktów docelowych ładunku, szczególnie wtedy, gdy część trasy przewozu poszczególnych grup wagonów - od punktu nadania do punktu przeznaczenia - pokrywa się. W trakcie przewozu, w optymalnym do tego celu punkcie, pociag towarowy grupowy jest dzielony, a grupy wagonowe kierowane sa do poszczególnych punktów docelowych jako nowo sformowane pociagi towarowe.

- pociag towarowy intermodalny - zestawiony $\mathrm{z}$ wagonów towarowych przeznaczonych do przewozów jednostek ładunkowych (takich jak kontenery, naczepy samochodowe lub całe samochody ciężarowe).

- $\quad$ pociagi zdawcze i zbiorowe - przeznaczone są do obsługi punktów ładunkowych przynależnych do rejonu obsługi danej stacji rozrządowej. Ich przeznaczeniem jest dostarczanie do tych punktów wagonów (ładownych i zamówionych próżnych pod załadunek) oraz zabieranie wagonów (po rozładunku albo załadowanych). Wagony po dostarczeniu na stację rozrządową są formowane $\mathrm{w}$ nowe pociagi i kierowane $\mathrm{w}$ dalszą drogę.

Pociagi odcinkowe - przeznaczone są do obsługi przewozów pomiędzy stacjami rozrządowymi. Wśród tego typu pociagów wyróżnić można pociagi towarowe dalekobieżne, których trasa przejazdu przebiega tranzytem przez co najmniej jedną stację rozrządową.

Jak wyżej wspomniano jako źródło napędu w pociagach towarowych wykorzystywana jest bardzo często - ze względu na ciaggle niewystarczająca elektryfikacją linii kolejowych w Polsce - lokomotywa spalinowa. Obecnie istniejące lokomotywy możemy podzielić na dwa typy:

- manewrowe - bardzo często dwukierunkowe, umożliwiające bezpieczną i szybką pracę związaną z przetokami towarów. Lokomotywy tego typu mają znacząco inny charakter pracy w porównaniu do lokomotyw użytkowanych w ruchu pasażerskim i towarowym. Duży procent pracy przypada na pracę silnika na biegu jałowym i małym obciążeniu. Charakter ładunku 
system is approx. $20 \mathrm{~kg} / \mathrm{kW}$. Of course, the power of diesel locomotives is systematically increased so that they can be operated to an even greater extent. There are locomotives with a power of over $2200 \mathrm{~kW}$ built in the Co-Co system, but in Europe, including Poland, the average power of the used construction is up to 1500 $\mathrm{kW}$. This is because these machines often also play a transfer-shunting role. There is also a separate group of shunting diesel locomotives with a power of up to 500 $\mathrm{kW}$. Such constructions are used during shunting the small groups of wagons, therefore they have an side sill - without bogie system of the running gear part [7].

A very important element worth paying attention to is the locomotive drive. In most designs, it is concentrated in one engine and even when there are the variable load conditions. At the same time, the modern combustion engines are created to concentrate the high power in a single unit, while remaining its low weight. The following parameters determine this:

- the average useful pressure, which is at a level of 23 bars

- rated revolutions, which are in the range 1000-2300 per minute.

The average speed of the piston is also important which in most locomotives it does not exceed $12 \mathrm{~m} / \mathrm{s}$. Moreover, the modern engines show a minimum of 190-205 g/kWh, while the consumption of lubricating oil usually do not exceed $0,15 \%$ of the consumption of fuel.

In the case of electric/hybrid locomotives (e.g.111DE locomotive) the tractive characteristics during traction with freight trains of $1500-3000 \mathrm{t}$ is as follows [4]:

- a locomotive powered from the traction network, delivering power of $2800 \mathrm{~kW}$ on a track without slope, will pull a train of wagons with a weight of $2000 \mathrm{t}$ at the travel speed of $110 \mathrm{~km} / \mathrm{h}$, with a drop of the shunting speed on a $7 \%$ hill to 53 $\mathrm{km} / \mathrm{h}$

- a locomotive powered by the traction unit, delivering power of $1560 \mathrm{~kW}$ on a track without slope, will pull the train of wagons with a weight of $2000 \mathrm{t}$ at the travel speed of $85 \mathrm{~km} / \mathrm{h}$, with a drop of shunting speed of $7 \%$ to $31 \mathrm{~km} / \mathrm{h}$.

The discussed locomotive (111DE) has been equipped with a modern generating set with the QSK60 combustion engine with a power of $2013 \mathrm{~kW}$ (Fig. 1.1) with the SCR exhaust gas treatment system. The combustion engine meets the requirements of Directive 97/68/EC of the European Parliament and Council stage IIIB (cycle F)) [4].

From the above, it can be noticed that for electric traction there is no decrease in traction power for the nominal power of $2800 \mathrm{~kW}$, because the power supply by a current collector allows the full use of the power of traction inverters and auxiliary converters. In the case of diesel traction, the power of the combustion engine is limited and additionally partially used for jest między innymi przyczyną dużego zużycia paliwa [3].

- do pracy pociaggowej - posiadające zdecydowanie większą moc w stosunku do manewrowych oraz poruszające się z większą prędkością.

Lokomotywa spalinowa wyróżnia się określoną specyfiką, która umożliwia jej bezproblemowe wykorzystywanie i zwiększa zakres działań. Wskaźnik masy własnej spalinowych lokomotyw pociagowych, odniesiony do mocy na obwodzie kół napędnych, pozostaje na poziomie $50-60 \mathrm{~kg} / \mathrm{kW}$, a jednostkowa masa samego układu napędowego wynosi ok. $20 \mathrm{~kg} / \mathrm{kW}$. Oczywiście moc lokomotyw spalinowych jest systematycznie powiększana, tak by możliwe było eksploatowanie ich w jeszcze większym stopniu. Istnieją lokomotywy o mocy ponad $2200 \mathrm{~kW}$ budowane w układzie Co-Co, jednak w Europie, w tym także w Polsce, przeciętna moc wykorzystywanych konstrukcji wynosi do 1500 $\mathrm{kW}$. Dzieje się tak, ponieważ maszyny te niejednokrotnie pełną także rolę zdawczo - manewrową. Istnieje także osobna grupa lokomotyw spalinowych manewrowych, o mocy do $500 \mathrm{~kW}$. Takie konstrukcje wykorzystywane są w przypadku przetaczania niewielkich grup wagonów, w związku z czym mają ostojnicowy bezwózkowy układ części biegowej [7].

Bardzo ważnym elementem, na który warto zwrócić uwage, jest napęd lokomotywy. W większości konstrukcji skupiony jest on $\mathrm{w}$ jednym silniku $\mathrm{i}$ to nawet $\mathrm{w}$ przypadku występowania zmiennych warunków obciążenia. Jednocześnie nowoczesne silniki spalinowe tworzone są tak, by skupić dużą moc w pojedynczym egzemplarzu, przy zachowaniu jego małej masy. Decydują o tym następujące parametry:

- średnie ciśnienie użyteczne, które kształtuje się na poziomie 23 barów

- obroty znamionowe, które mieszczą się w zakresie 1000-2300 na minutę.

Duże znaczenie ma także średnia prędkość tłoka, która w większości lokomotyw nie przekracza $12 \mathrm{~m} / \mathrm{s}$. Ponadto nowoczesne silniki wykazują minimum 190 $205 \mathrm{~g} / \mathrm{kWh}$, natomiast rozchody oleju smarnego nie przekraczają zazwyczaj $0,15 \%$ rozchodów paliwa.

W przypadku lokomotyw elektrycznych/ hybrydowych (itp. Lokomotywa 111DE) charakterystyka pociagowa podczas trakcji z pociagami towarowymi o masie 1500 - 3000 t kształtuje się następująco [4]:

- lokomotywa zasilana z sieci trakcyjnej, realizując moc $2800 \mathrm{~kW}$ na torze bez pochylenia pociagnie z prędkością przejazdu $110 \mathrm{~km} / \mathrm{h}$ skład wagonów o masie 2000 t, przy spadku prędkości przetokowej na wzniesieniu $7 \%$ do $53 \mathrm{~km} / \mathrm{h}$

- lokomotywa zasilana rzez agregat trakcyjny, realizując moc $1560 \mathrm{~kW}$ na torze bez pochylenia pociagnie z prędkością przejazdu $85 \mathrm{~km} / \mathrm{h} \mathrm{skład}$ wagonów o masie 2000 t, przy spadku prędkości przetokowej na wzniesieniu $7 \%$ do $31 \mathrm{~km} / \mathrm{h}$. 
supplying, etc. the hydrostatic drive of the cooling system fans. The difference in power for traction (passenger and freight) purposes results from the need to heat the passenger wagons in winter and cool them in summer [4].

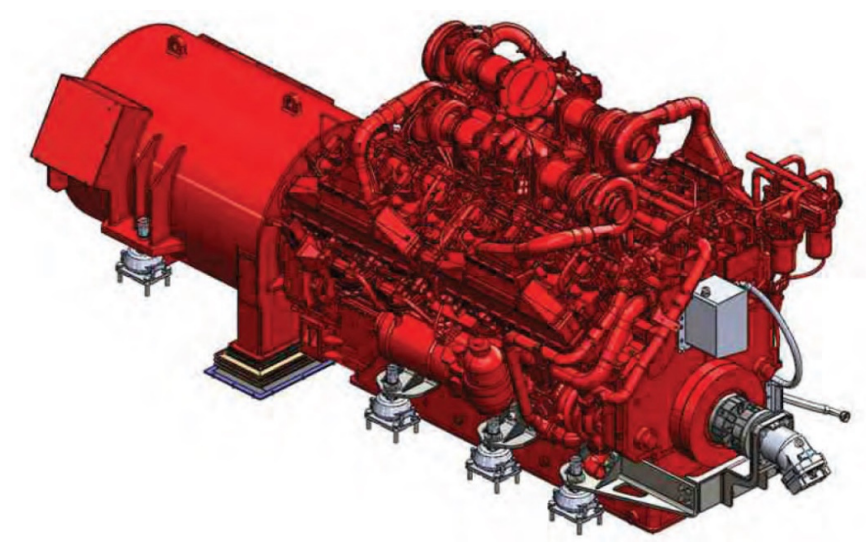

Rys. 1.1 Agregat prądotwórczy $3 \mathrm{KV}_{\mathrm{DC}}[9]$

Fig. 1.1 Power $3 \mathrm{KV}_{\mathrm{DC}}$ generator [9]

Producent/Producer Cummins

Typ/Type QSK60 - L2700

Moc znamionowa/Rated power.....................

broty znamionowe silnika spalinowego/ Nominal revolutions of the combustion engine. $1800 \mathrm{obr} / \mathrm{min} / \mathrm{rpm}$

Ilość i układ cylindrów/ Number and configuration $16 \mathrm{w}$ układzie V/16 in of cylinders . $2013 \mathrm{~kW}$

Masa silnika (zalanego)/Engine weight

(flooded) $9159 \mathrm{~kg}$

Jednostkowe zużycie paliwa/Elementary fuel consumption $204 \mathrm{~g} / \mathrm{kWh}$

Rozruch silnika/Engine starting-up. elektryczny/electric

Regulator pracy silnika/ Engine work regulator ....... elektroniczny/electronic

Norma emisji spalin/ Exhaust etap IIIB wg dyrektywy emission standard 2004/26/WE/ stage III according to Directive 2004/26/EC

Due to the high competitiveness on the freight transport market, it becomes necessary to strive to build the vehicles that meet the requirements of high availability, functionality, versatility, in line with proecological trends, economical in maintenance, with a low tare weight, characterized by the high payload.
W omawianej lokomotywie (111DE) zabudowano nowoczesny zespół prądotwórczy z silnikiem spalinowym QSK60 o mocy 2013kW (rys. 1.1) z układem oczyszczania spalin SCR. Silnik spalinowy spełnia wymagania Dyrektywy 97/68/WE Parlamentu Europejskiego i Rady etap IIIB (cykl F) [4].

$\mathrm{Z}$ powyższego można zauważyć, że dla trakcji elektrycznej nie występuje spadek mocy na cele trakcyjne w stosunku do mocy nominalnej $2800 \mathrm{~kW}$, ponieważ zasilanie przez odbierak prądu pozwala na pełne wykorzystanie mocy przekształtników trakcyjnych i przetwornic pomocniczych. W przypadku trakcji spalinowej, moc silnika spalinowego jest ograniczona $i$ dodatkowo częściowo zużywana na zasilanie itp. układu hydrostatycznego napędu wentylatorów układu chłodzenia. Różnica w mocy na cele trakcyjne (osobowe $\mathrm{i}$ towarowe) wynika $\mathrm{z}$ konieczności ogrzewania zimą i chłodzenia latem wagonów osobowych [4].

$\mathrm{Z}$ uwagi na dużą konkurencyjność na rynku przewozu towarów, koniecznym staje się dążenie do budowy pojazdów spełniajacych wymogi wysokiej dyspozycyjności, funkcjonalności, uniwersalności, wpisujących się $\mathrm{w}$ tendencje proekologiczne, ekonomicznych w utrzymaniu, o niskiej masie własnej, charakteryzujących się dużą ładownością.

Istotnym podzespołem, decydującym o wielu parametrach wagonu towarowego, do jakich należą:

- masa usprężynowana i masa nieusprężynowana (masa omaźnicowanego zestawu kołowego)

- wytrzymałość statyczna i zmęczeniowa elementów nośnych do jakich należą: rama, maźnice, elementy usprężynowania i układu hamulcowego, zestawy kołowe (koła i osie)

- dopuszczalna ładowność i prędkość

- bezpieczeństwo w warunkach jazdy quasistatycznej podczas przejazdu przez tory o ograniczonej wichrowatości

- właściwości dynamiczne (dopuszczalne przyspieszenia pionowe i poprzeczne mierzone na maźnicach i ramie wózka) oraz siły oddziaływania na tor i elementy nawierzchni kolejowej

- zdolność do hamowania realizowaną na drogach hamowania określonych $\mathrm{w}$ przepisach, limitowaną przez odległość międzysygnałową

- przejezdność przez łuk o minimalnym promieniu $(\mathrm{R}=35 \mathrm{~m}$ lub $\mathrm{R}=75 \mathrm{~m}$ w zależności od typu wagonu towarowego - tego typu łuki nie występują na liniach kolejowych, a jedynie stanowią element infrastruktury wewnątrz zakładowej zakładów naprawczych taboru, hal produkcyjnych itp.)

- zdolność do wjazdu na promy o określonym kącie pochylania rampy i ewentualnie promieniu łuku toru,

- zdolność przejazdu przez rozjazdy i skrzyżowania toru 
- suspended mass and non-suspended mass (mass of the wheelset with the axle-box)

- static and fatigue strength of load-bearing elements, which include: frame, axle - boxes, suspension and brake system elements, wheelsets (wheels and axles)

- permissible payload and speed

- safety in quasi-static riding conditions during riding on the tracks with limited twist

- dynamic properties (permissible vertical and lateral accelerations measured on axle- boxes and bogie frame) and forces acting on the track and track structure elements

- ability to braking on braking distances specified in the regulations, limited by the distance between signals

- passage on a curve with a minimum radius $(\mathrm{R}$ $=35 \mathrm{~m}$ or $\mathrm{R}=75 \mathrm{~m}$ depending on the type of freight wagon - such curves do not occur on the railway lines, but are only an element of infrastructure inside the company's rolling stock repair plants, production halls, etc.)

- ability to enter ferries with a specific ramp inclination angle and possibly the track curve radius,

- ability to pass through turnout and crossings of track

- ability to ride over humps, track brakes and other infrastructure brake equipment

- level of maintenance and repair works of the wagon that must be performed to keep the vehicle in working order

- safety and occupational health during unloading and loading of the wagon, the level of vibration emission, oscillations and shocks (shock loads)

- level of noise emissions to the environment

- wear resistance of parts and level of corrosion protection

- adjusting ability on a wide track with a gauge of $1520 \mathrm{~mm}$

- ability to cooperation (compatibility) with relevant infrastructure devices and devices for railway traffic control (SRK)

- providing high reliability through the appropriate design of structural nodes that do not require repairs and maintenance and the use of generally available spare parts

- optimal use of the cargo space by using the compact structures in the lower parts of the wagon

- space for assembly and disassembly of the automatic coupler (AK)

- providing the minimum and maximum allowable height of the buffers and screw coupler (or AK) relative to the level of rail
- zdolność przejazdu przez górki rozrządowe, hamulce torowe oraz inne urządzenia hamulcowe infrastruktury

- poziom prac konserwacyjno - naprawczych wagonu, które należy wykonać, aby utrzymać pojazd w stanie gotowości do eksploatacji

- bezpieczeństwo i higiena pracy podczas rozładunku i załadunku wagonu, poziom emisji drgań, wibracji i wstrząsów (obciążeń udarowych)

- poziom emisji hałasu do środowiska naturalnego

- odporność części na zużycie i poziom zabezpieczenia przed korozją

- zdolność do przestawności na szeroki tor o prześwicie $1520 \mathrm{~mm}$

- zdolność do współpracy (kompatybilność) z odpowiednimi urządzeniami infrastruktury i urządzeniami do sterowania ruchem kolejowym (SRK)

- zapewnienie wysokiej niezawodności poprzez odpowiednie projektowanie węzłów konstrukcyjnych, niewymagających napraw i konserwacji oraz stosowanie ogólnie dostępnych części zamiennych

- optymalne wykorzystanie przestrzeni ładunkowej poprzez stosowanie zwartych konstrukcji w dolnych partiach wagonu

- przestrzeń do montażu i demontażu sprzęgu automa-tycznego (AK)

- zapewnienie minimalnej i maksymalnej dopuszczalnej wysokości zderzaków oraz sprzęgu śrubowego (lub AK) względem poziomu główki szyny jest, w przypadku wagonów towarowych dwuosiowych zawieszenie, a w przypadku wagonów towarowych cztero i sześcio-osiowych układ biegowy lub wózek (odpowiednio 2 - osiowy lub trójosiowy).

\section{HISTORIA}

Jak wcześniej wspomniano, konieczność stosowania wieloosiowych wózków w wagonach towarowych wynika przede wszystkim $\mathrm{z}$ ograniczeń w naciskach zestawów kołowych na tor oraz, w przypadku wagonów towarowych dwuosiowych, minimalnej bazy wagonu. Tendencja ta jest tak zaawansowana, że w obecnie budowa wagonów towarowych dwuosiowych ma ograniczony zakres w skali europejskiej.

Większość współcześnie stosowanych wagonów towarowych wyposażona jest w wózki dwuosiowe, jednakże można również spotkać układy biegowe trzy lub wieloosiowe ale te pojazdy należą do pojazdów specjalnych.

Pod względem konstrukcyjnym rozróżnia się dwa podstawowe rodzaje wózków: $\mathrm{z}$ ostoją $\mathrm{w}$ formie ramy z belką skrętową i kulistym czopem skrętu (itp. 1Xta, $25 \mathrm{TNa}$ ) oraz $\mathrm{z}$ ostoją $\mathrm{w}$ kształcie litery $\mathrm{H}$ złożoną $\mathrm{z}$ dwóch ostojnic i usprężynowanej belki bujakowej z 
- providing the minimum and maximum czopem płaskim (itp. 2Xta). W tablicy 1 przedstawiono allowable height of the buffers and screw parametry ważniejszych typów wózków stosowanych coupler (or AK) relative to the level of rail $\mathrm{w}$ wagonach towarowych polskich przewoźników oraz head It is, in the case of two-axle freight innych podmiotów poruszających się po liniach PLK wagons, the suspension, and in the case of PKP S.A.

four- and six-axle freight wagons, the running gear or bogie (2-axle or tri-axle respectively).

Parametry ważniejszych typów wózków stosowanych w wagonach towarowych [2] Tablica 1 Parameters of the more important types of bogies used in the freight wagons [2] Table1

\begin{tabular}{|c|c|c|c|c|c|c|c|c|c|c|c|}
\hline \multirow[b]{2}{*}{ 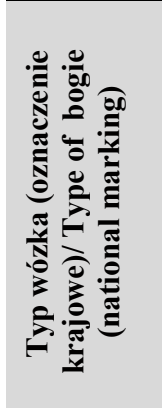 } & \multirow[b]{2}{*}{ 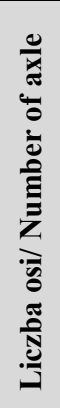 } & \multirow[b]{2}{*}{ 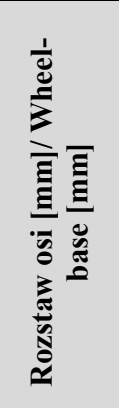 } & \multirow[b]{2}{*}{ 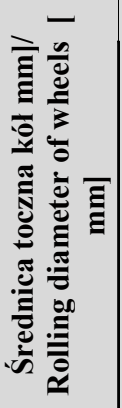 } & \multirow[b]{2}{*}{ 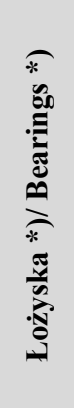 } & \multicolumn{4}{|c|}{ Usprężynowanie/Suspension } & \multirow[b]{2}{*}{ 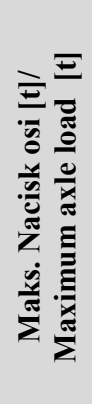 } & \multirow[b]{2}{*}{ 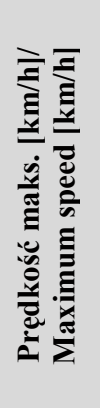 } & \multirow[b]{2}{*}{ 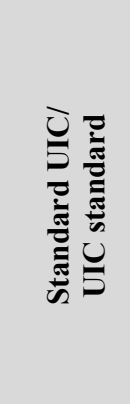 } \\
\hline & & & & & 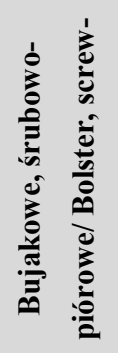 & 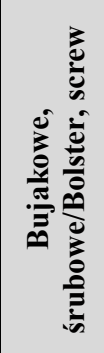 & 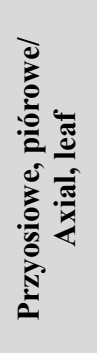 & 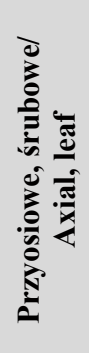 & & & \\
\hline )iamond $\mathrm{A} 1$ & 2 & 1800 & 960 & $\dot{S}$ & • & & & & 20 & 80 & no \\
\hline Chanin N & 2 & 1850 & 950 & $\dot{S} / \mathrm{T}$ & & $\bullet$ & & & 20 & 80 & no \\
\hline $2 \mathrm{Xta}$ & 2 & 1850 & 960 & $\mathrm{~T}$ & & - & & & 20 & 80 & no \\
\hline $20 \mathrm{R}$ & 2 & 1800 & 940 & Ś & & & $\bullet$ & & 18 & 80 & no \\
\hline 28R, 1XT & 2 & 2000 & 1000 & $\mathrm{~T}$ & & & $\bullet$ & & 20 & 100 & $\mathrm{no}^{\mathrm{xx}}$ \\
\hline $26-2.8$ & 2 & 2000 & 920 & $\mathrm{~T}$ & & & • & & 20 & 100 & no \\
\hline 1Xta & 2 & 2000 & 920 & $\mathrm{~T}$ & & & • & & 20 & 100 & $\mathrm{no}^{\mathrm{xx}}$ \\
\hline 25 Tna & 2 & 1800 & 920 & $\mathrm{~T}$ & & & & • & 20 & 100 & Y25Cs2 \\
\hline 26Tna & 2 & 1800 & 920 & $\mathrm{~T}$ & & & & $\bullet$ & 20 & 120 & Y25Rs2a \\
\hline $3 \mathrm{TNh}$ & 2 & 1800 & 920 & $\mathrm{~T}$ & & & & $\bullet$ & 22,5 & 100 & Y25Lsd \\
\hline $3 \mathrm{TNf}$ & 2 & 1800 & 920 & $\mathrm{~T}$ & & & & • & 22,5 & 100 & Y25Lsd1 \\
\hline $15 \mathrm{TN}$ & 2 & 1800 & 920 & $\mathrm{~T}$ & & & & $\bullet$ & 25 & 100 & no \\
\hline $5 \mathrm{TN}$ & 2 & 2300 & 840 & $\mathrm{~T}$ & & & & $\bullet$ & 18 & 160 & Y37B \\
\hline $16 Z$ & 3 & $2 \times 1500$ & 940 & $\dot{S}$ & & & $\bullet$ & & 18 & 80 & no \\
\hline $7 \mathrm{TN}$ & 3 & $2 \times 1600$ & 920 & $\mathrm{~T}$ & & & • & & 20 & 100 & no \\
\hline 7Tna & 3 & $2 \times 1600$ & 920 & $\mathrm{~T}$ & & & - & & 20 & 100 & no \\
\hline UWZ-11A & 3 & $2 \times 1750$ & 950 & $\mathrm{~T}$ & & $\bullet$ & & & 20 & 70 & no \\
\hline $609 \mathrm{Z}$ & 4 & $3 \times 1500$ & 940 & $\mathrm{~T}$ & & & - & & 20 & 100 & no \\
\hline
\end{tabular}

*) Ś - tożyska ślizgowe/ plain bearings, $T$ - tożyska toczne/ rolling bearings

\section{HISTORY}

As mentioned before, the necessity to use the multiaxle bogies in freight wagons results first of all from the limitations in the loads of the wheelsets on the track and, in the case of two-axle freight wagons, the minimum base of wagon. This trend is so advanced
W 1967 r poprzez wspólne działania Urzędu Badań i Prób Międzynarodowych (ORE) i Europejskiego Instytutu Badań Kolejowych (ERRI) rozpoczęto prace związane z wytypowaniem wózków przeznaczonych do standaryzacji. W ramach wspominanych prac standaryzacyjnych opracowano dokumentacje konstruk- 
that currently the construction of two-axle freight wagons is limited on the European scale.

Most of the freight cars used today are equipped with two-axle bogies, however, three-axle or multi-axle gear systems can be also met, but these vehicles belong to the special vehicles.

In terms of construction two basic types of bogies are distinguished: with frame in the shape of frame with the main pivot beam and ball bogie pivot (e.g. 1Xta, 25Tna) and the H-shaped frame consisting of two side-sills and suspended bolster beam with the flat pivot (e.g. 2Xta). Table 1 presents the parameters of the more important types of bogies used in the freight wagons of Polish carriers and other entities operating on the PLK PKP S.A lines.

In 1967 the works were started related to the selection of bogies intended for standardization through joint activities of the International Research and Trials Office (ORE) and the European Railway Research Institute (ERRI). As part of the mentioned standardization works, the constructional documentation of individual types of bogies was developed for railways associated in the International Union of Railways (UIC).

According to the decisions taken by ORE/ERRI, standard bogies should meet the following geometrical conditions [1]:

- the outline of the bogie construction should be within the spatial outline presented in Fig. 2.1

- bogie base should be $1800 \mathrm{~mm}$

- the use of bogie pin having the shape of a spherical cap with a radius of $190 \mathrm{~mm}$

- height of the center of the bogie pin ball from the level of rail head for a total weight of wagon of $20 \mathrm{t}$ : $925 \mathrm{~mm}$

- height of the side bearers surface from the rail head: $900 \mathrm{~mm}$

- distance of the side bearers from the longitudinal axis of the bogie: $850 \mathrm{~mm}$

- ratio of the brake lever system: $\mathrm{i}=4$

- distance from the „A" connection point of the brake on the bogie with the mechanical part of the brake on the wagon underframe: $993 \mathrm{~mm}$ from the axis of the bogie pin and $760 \mathrm{~mm}$ from the rail head level with the total weight wagon of $20 \mathrm{t}: 760 \mathrm{~mm}$, in this case the dimensions are applied when the brake is released and brake shoe inserts adhere to the wheels - Fig. 2.2

- between two manual movements of the "A" point of the fixed brake the fixed dimension of the movement of the connection point is applied, which moves in total by $255 \mathrm{~mm}$ - Fig. 2.2. This displacement consists of a total of wear of brake shoe inserts by $50 \mathrm{~mm}$ as a result of partial wear of wheels and joints ( pin - sleeve). The cyjne poszczególnych typów wózków dla kolei zrzeszonych w Międzynarodowym Związku Kolei (UIC).

Zgodnie z ustaleniami podjętymi przez ORE/ERRI wózki standardowe powinny spełniać następujące warunki geometryczne [1]:

- zarys konstrukcji wózka powinien mieścić się w zarysie przestrzennym, przedstawionym na rys. 2.1

- baza wózka powinna wynosić $1800 \mathrm{~mm}$

- zastosowanie gniazda skrętu posiadającego kształt czaszy kulistej o promieniu $190 \mathrm{~mm}$

- wysokość środka kuli gniazda skrętu wózka od poziomu główki szyny dla wagonu o masie całkowitej 20t: $925 \mathrm{~mm}$

- wysokość płaszczyzny ślizgów od główki szyny: $900 \mathrm{~mm}$

- odległość ślizgów bocznych od osi wzdłużnej wózka: $850 \mathrm{~mm}$

- przełożenie układu dźwigniowego hamulca: $\mathrm{i}=4$

- odległość punktu „A” podłączenia hamulca na wózku z częścią mechaniczną hamulca na ostoi wagonu: $993 \mathrm{~mm}$ od osi gniazda skrętu i $760 \mathrm{~mm}$ od poziomu główki szyny dla wagonu o masie całkowitej 20t: $760 \mathrm{~mm}$, w tym przypadku wymiary obowiązują dla przypadku kiedy hamulec jest w stanie zluzowanym i wstawki klocków hamulcowych przylegają do kół - rys. 2.2

- pomiędzy dwoma manualnymi przestawieniami punktu „A" stałego hamulca obowiązuje ustalony wymiar przesunięcia punktu podłączenia, który przemieszcza się łącznie o $255 \mathrm{~mm}$ - rys. $2.2 \mathrm{Na}$ przemieszczenie to składa się łączne zużycie wstawek klocków hamulcowych o $50 \mathrm{~mm}$ w wyniku częściowego zużycia kół i przegubów (sworzeń - tulejka). Wymiar $55 \mathrm{~mm}$ przyjęto jako minimalny, który został uznany jako odległość pomiędzy otworami punktu stałego hamulca.
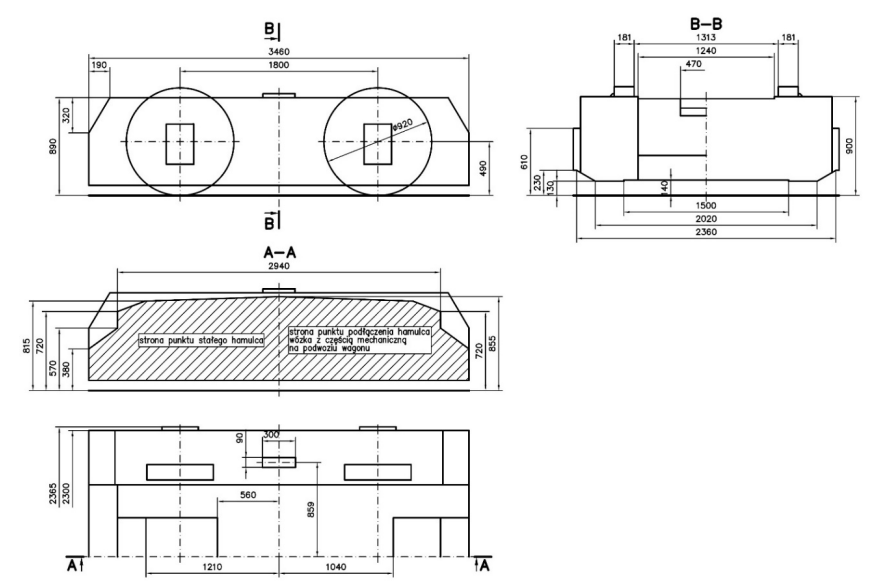

Rys. 2.1 Zarys przestrzenny dla standardowych wózków wagonów towarowych [4]

Fig. 2.1 Spatial outline for standard freight wagon bogies [4] 
dimension of $55 \mathrm{~mm}$ is taken as the minimum which was considered as the distance between the holes of the brake fixed point.
Legenda/Legend: strona punktu stałego hamowania- side of point of fixed braking, strona punktu podłączenia hamulca wózka $\mathrm{z}$ cześcią mechaniczną na podwoziu wagonu - side of connection point of gogie brake with the mechanical part on the wagon running gear
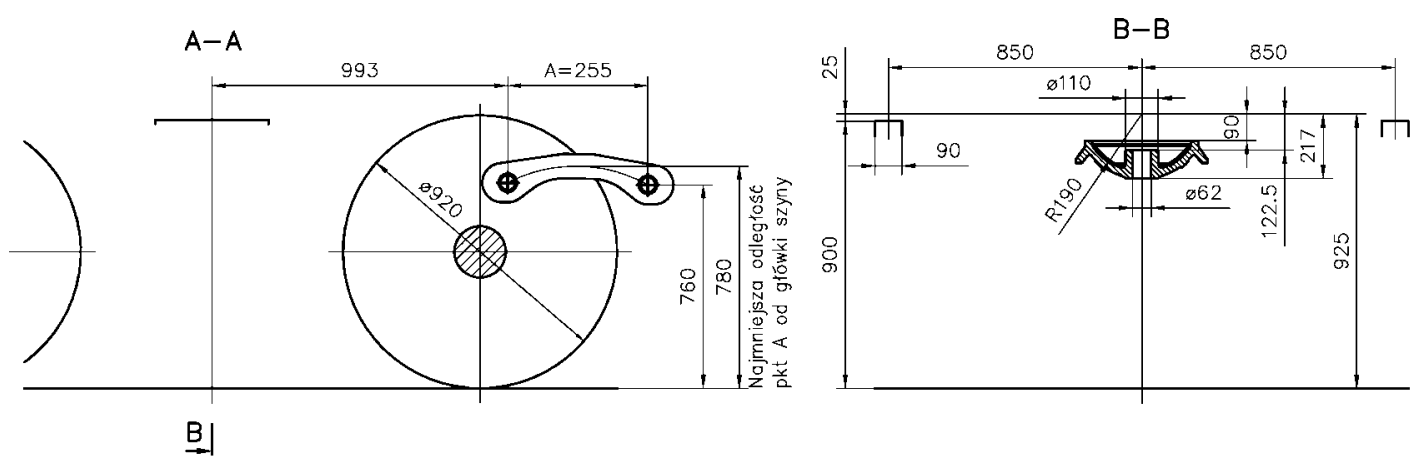

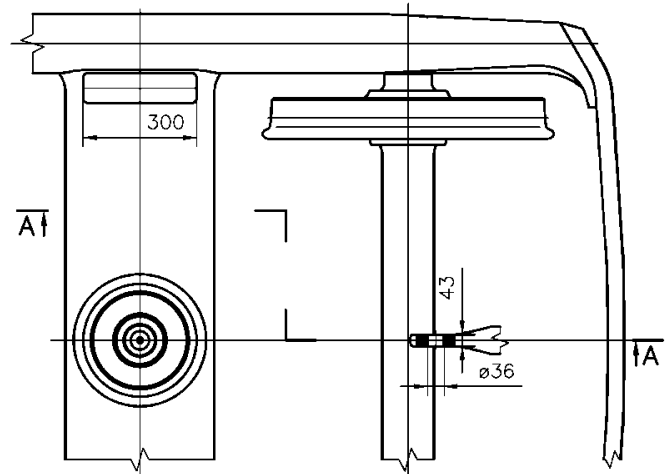

$\overrightarrow{\mathrm{B}}$

\begin{abstract}
Rys. 2.2 Wymiary dla
zamienności wózka standardowego do wagonów towarowych [4]

Fig. 2.2 Dimensions for interchangeability of the standard bogie to freight wagons
\end{abstract}

[4]

Legenda/legend: najmniejsza odległość pkt A od główki szyny/ the shortest distance between point $\mathrm{A}$ and the head of the rail
The other requirements for interchangeability are specified in UIC510-1 leaflet [4].

Due to the non-fulfillment of the above-mentioned criteria by the bogie of 1XT type submitted by PKP (too large bogie base), since the mid-1870s the standardized bogies of the French design of Y25 standard were used in Polish wagons in accordance with UIC recommendations. Taking into consideration the above-mentioned criteria, a list of standardized bogies intended for freight wagons was developed. The list is included in the table 2 .
Pozostałe wymagania w zakresie zamienności podano w karcie UIC510-1 [4].

Ze względu na niespełnienie wyżej wymienionych kryteriów przez zgłoszony przez PKP wózek typu 1XT (za duża baza wózka) od połowy lat 70 XIX w. w polskich wagonach stosowano znormalizowane wózki francuskiej konstrukcji standardu Y25, zgodnie z zaleceniami UIC. Mając na uwadze wyżej wymienione kryteria opracowano wykaz standaryzowanych wózków przeznaczonych dla wagonów towarowych. Wykaz zawarto w tablicy 2.
Tablica wózków standaryzowanych dla wagonów towarowych Table of standardized bogies for freight wagons
Tablica 2

Table2

\begin{tabular}{|c|c|c|c|c|c|c|}
\hline \multirow{2}{*}{ 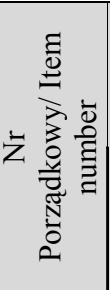 } & \multirow{2}{*}{ Oznaczenie/ Designation } & \multicolumn{3}{|c|}{$\begin{array}{l}\text { Normalizowany } \\
\text { wg stopnia/ } \\
\text { Standardized by } \\
\text { degree }\end{array}$} & \multicolumn{2}{|c|}{ Podany w/ Specified in } \\
\hline & & 4 & 5 & 6 & $\begin{array}{l}\text { Karcie UIC Nr/ } \\
\text { UIC leaflet No. }\end{array}$ & $\begin{array}{l}\text { Wykazie rysunków ERRI } \\
\mathrm{Nr} \text { / List of drawings } \\
\text { ERRI No. }\end{array}$ \\
\hline 1 & $\begin{array}{l}\text { Wózki przystosowane do nacisku } \\
\text { zestawu kolowego na tor } 196,13 \mathrm{kN} \mathrm{N}^{\mathrm{a}}(20 \mathrm{t}) / \\
\text { Bogies adapted to the load of the } \\
\text { wheelset on the track of } 196.13 \mathrm{kN}^{\mathrm{a}}(20 \mathrm{t})\end{array}$ & & & & $510-1$ & \\
\hline 1.1 & Wózek Y25Rs/ Y25Rs bogie & & & $\mathrm{X}$ & & M12030020 \\
\hline 1.2 & Wózek Y25Rss/ Y25Rss bogie & & & $\mathrm{X}$ & & M12030023 \\
\hline 1.3 & Wózek Y25Rs/ Y25Rs bogie & & & $\mathrm{X}$ & & M12030024 \\
\hline 1.4 & Wózek Y25Rsif/ Y25Rsif bogie & & & $\mathrm{X}$ & & M12030025 \\
\hline 1.5 & Wózek Y25Rsa/ Y25Rsa bogie & & & $\mathrm{X}$ & & M12030026 \\
\hline
\end{tabular}




\begin{tabular}{|c|c|c|c|c|}
\hline 1.6 & Wózek Y25Rssa/ Y25Rssa bogie & $\mathrm{X}$ & & M12030029 \\
\hline 1.7 & Wózek Y25Rsm/ Y25Rsm bogie & $\mathrm{X}$ & & M1203 0030 \\
\hline 1.8 & Wózek Y25Rssm/ Y25Rssm bogie & $\mathrm{X}$ & & M12030033 \\
\hline 1.9 & Wózek Y25Rsim/ Y25Rsim bogie & $\mathrm{X}$ & & M12030034 \\
\hline 1.10 & Wózek Y25Rifm/ Y25Rifm bogie & $\mathrm{X}$ & & M12030035 \\
\hline 2 & $\begin{array}{l}\text { Wózki przystosowane do nacisku } \\
\text { zestawu kołowego na tor } 220,65 \mathrm{kN} \\
(22,5 \mathrm{t}) / \text { Bogies adapted to the load of the } \\
\text { wheelset on the track of } 220.65 \mathrm{kN}(22.5 \mathrm{t})\end{array}$ & & $510-1$ & \\
\hline 2.1 & Wózek Y25Lsd/ Y25Lsd bogie & $\mathrm{X}$ & & M12030038 \\
\hline 2.2 & Wózek Y25Lsd1/ Y25Lsd1 bogie & $\mathrm{X}$ & & M12030039 \\
\hline 2.3 & Wózek Y25Lsdm/ Y25Lsdm bogie & $\mathrm{X}$ & & M12030040 \\
\hline 2.4 & Wózek $65 \mathrm{sd} / 65 \mathrm{sd}$ bogie & $\mathrm{X}$ & & M12030065 \\
\hline 2.5 & Wózek Y25Lsod/ Y25Lsod bogie & $\mathrm{X}$ & & M12030046 \\
\hline 2.6 & Wózek Y25Ls(s)i1/ Y25Ls(s)i1 bogie & $\mathrm{X}$ & & M12030042 \\
\hline 2.7 & Wózek Y25Ls(s)i2/ Y25Ls(s)i2 bogie & $\mathrm{X}$ & & M12030043 \\
\hline 2.8 & Wózek Y25Ls(s)if1/ Y25Ls(s)if1 bogie & $\mathrm{X}$ & & M12030044 \\
\hline 2.9 & Wózek Y25Ls(s)if2/ Y25Ls(s)if2 bogie & $\mathrm{X}$ & & M12030045 \\
\hline
\end{tabular}

65

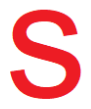

Y

ogólny symbol wózka

25

numer wózka

przedstawionego do

standardyzacji

system ogólny wózków pochodzących od kolei

DB posiadających usprężynowanie resorami

parabolicznymi (wózek do nacisku 22,5 t/oś)

"s" - stosuje się dla obciążenia 20 t/oś w ruchu s (100 km/h) -

hamowanie przez 8 wstawek klocków hamulcowych

"sd" - stosuje się dla obciążenia 22,5 t/oś w ruchu s $(100 \mathrm{~km} / \mathrm{h})$ -

hamowanie przez 16 wstawek klocków hamulcowych

"D" - rozważa się w ERRI przyjąć tą literę w oznaczeniu wózków z

hamulcem tarczowym

"R" - wózki 20 t/oś wzmocnione

"C" - wózki 20 t/oś

"L" - wózki 22,5 t/oś

"s" - dla wszystkich wózków Y25: 20 t/oś w ruchu S $(100 \mathrm{~km} / \mathrm{h})$

"s2" - dla wózków T25C i R do 20 t/oś, dla ruchu S $(100 \mathrm{~km} / \mathrm{h})$ z predyspozycją do ruchu SS (120 km/h)

"sd" - dla wózków Y25 - 22,5 t/oś dla ruchu S (100 km/h) z klockami dwuwstawkowymi

"ss" - dla wózków Y25C i Y25R do 20t/oś w ruchu SS (120 km/h)

"s(s)" - dla wózków Y25I - 22,5 t/oś w ruchu s (100 km/h) oraz 20 t/oś w ruchu SS (120 km/h)

brak litery - przekładnia hamulcowa na wózku - cylinder i nastawiacz klocków na podwoziu wagonu

"i" - dla wózka Y25 i Y25R - cylinder i nastawiacz klocków umieszczone na ramie wózka

"i1" - dla wózka Y25L - dwa cylindry hamulcowe działające w układzie posobnym TANDEM

nastawiacz klocków i przekładnik ciśnienia zamontowane na wózku

"i2" - dla wózka Y25L - dwa cylindry hamulcowe działające w układzie posobnym i nastawiacz klocków zamontowane na wózku - przekładnik ciśnienia zamontowany na podwoziu wagonu

"f" - dla wózków Y25C, R i L posiadających cylindry hamulcowe i nastawiacze klocków na ramie

wózka - hamulec postojowy (ręczny) z przekładnia i kołem pokrętnym na ramie wózka

brak litery - rama podstawowa ze szkieletem stalowym spawanym, a w wózku 22,5 t/oś z podłużnicami w wersji BR-PKP

"1" - dla wózków 22,5 t/oś Y25I podłużnice w wersji SNCF. Przykręcane

do belki skretowei. a oparte na ślizau na czołownicv

"a" - wskazuje, że w wózkach wzmocnionych Y25R - 20 t/oś ulepszone podłużnice spawane wykonywane są wg wariantu BR-PKP

"m" - rama wózka ze staliwa

"o" - dla wszystkich wózków Y25 wskazuje obecność osi sanonastawnych - dwa tłumiki ceirne na każdej maźnicy 


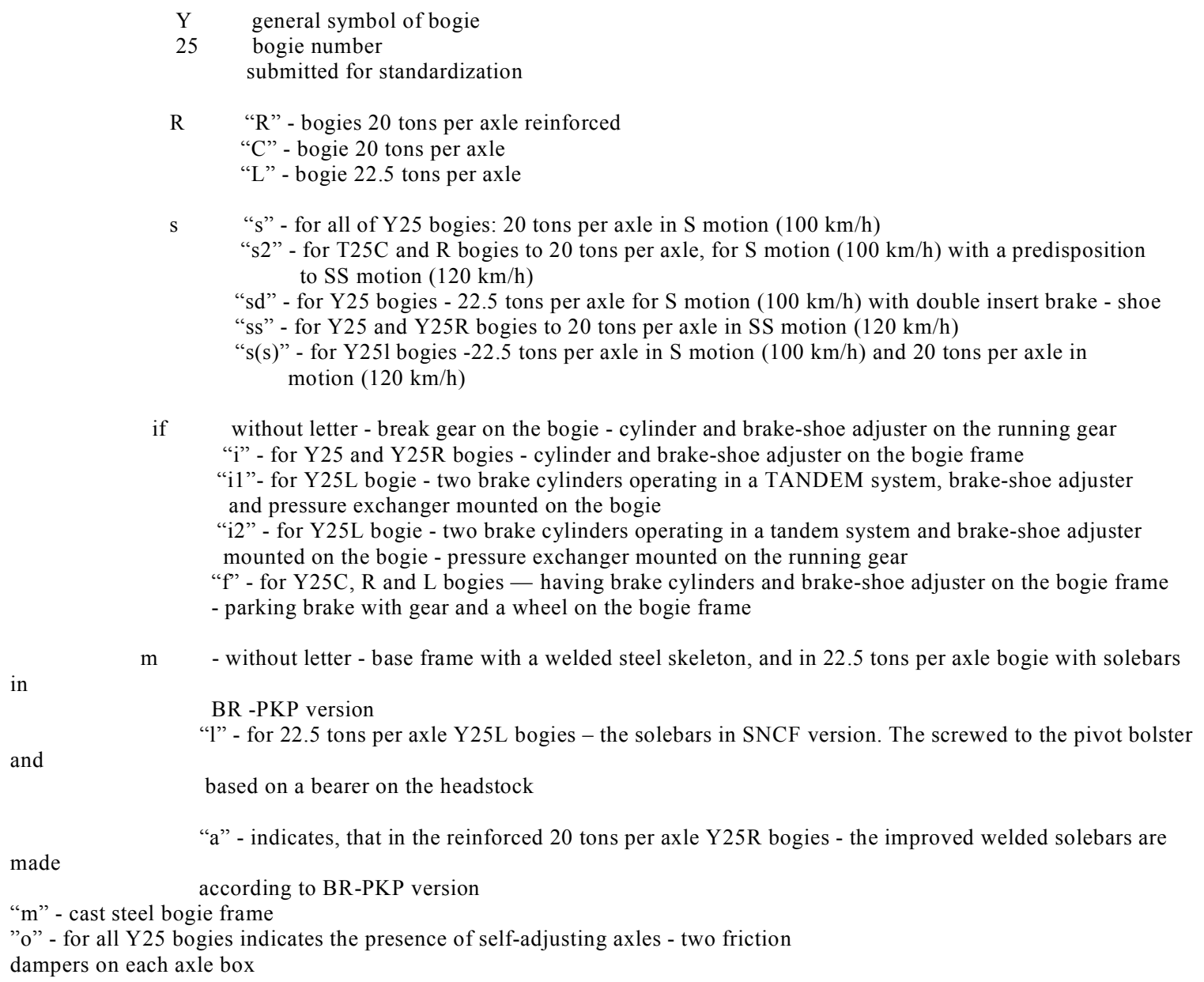

Rys. 2.4 Sposób tworzenia symboli wózka standardowego typu Y25 [opracowanie własne]

Fig. 2.4 The way of forming symbols of a standard bogie of Y25 type [own study]

a) Starting in October 1963, the use of reinforced bogies of the Y25 variant, which is considered as the base version, is recommended for all new freight wagons. The railways can continue to use the $\mathrm{Y} 25 \mathrm{C}$ bogie if they wish it.

Table 2 shows that 2 types of bogies were submitted for standardization - bogie of Y 25 type and bogie of 65 type, where bogie of Y25 type can occur in many configurations depending on the requirements and purpose. The rules of marking of standardized bogies are presented in Fig. 2.3 and Fig.2.4

Apart the above-mentioned standard bogies, the International Union of Railways UIC allows the following types of bogies to be used for $\mathrm{S}$ motion $(100 \mathrm{~km} / \mathrm{h})$ and SS motion $(120 \mathrm{~km} / \mathrm{h})[1]$ :

- bogies for S motion: DB 665, DB 641/642, Y21, Y27, Y31, Y35, Y37, Y37A, Y37B, DB 661, DB 664, DB 931, Y19A, Y33A(m)

- bogies for SS motion: Y21, DB664, Y37A, Y37B, Y33A(m), Y27, Y31, Y35. a) Począwszy od października 1963 - stosowanie wózków wzmocnionych wariantu Y25, który jest uważany za wersje bazową, zalecane jest dla wszystkich nowych wagonów towarowych. Koleje, które sobie tego życzą moga jednakże kontynuować stosowanie wózka Y25C.

Z tablicy 2 wynika, że zgłoszono do standaryzacji 2 typy wózków - wózek typu Y25 oraz wózek typu 65, przy czym wózek typu Y25 może występować w wielu konfiguracjach, w zależności od wymagań i przeznaczenia. Zasady znakowania wózków standardowych zostały przedstawione na rys. 2.3 oraz rys. 2.4

Poza wyżej wymienionymi wózkami standardowymi, Międzynarodowy Związek Kolei UIC dopuszcza do stosowania dla ruchu $\mathrm{S}(100 \mathrm{~km} / \mathrm{h})$ oraz $\mathrm{SS}$ $(120 \mathrm{~km} / \mathrm{h})$ następujące rodzaje wózków [1]:

- wózki dla ruchu S: DB 665, DB 641/642, Y21, Y27, Y31, Y35, Y37, Y37A, Y37B, DB 661, DB 664, DB 931, Y19A, Y33A(m)

- wózki dla ruchu SS: Y21, DB664, Y37A, Y37B, Y33A(m), Y27, Y31, Y35.

\section{EXAMPLES OF RUNNING FREIGHT WAGONS 3.1.1Xta bogie}

$1 \mathrm{Xta}$ bogie is presented in fig. 3.1.

\section{PRZYKLADY UKLADÓW BIEGOWYCH WAGONÓW TOWAROWYCH 3.1. Wózek 1Xta}

Wózek 1Xta przedstawiono na rys. 3.1. 

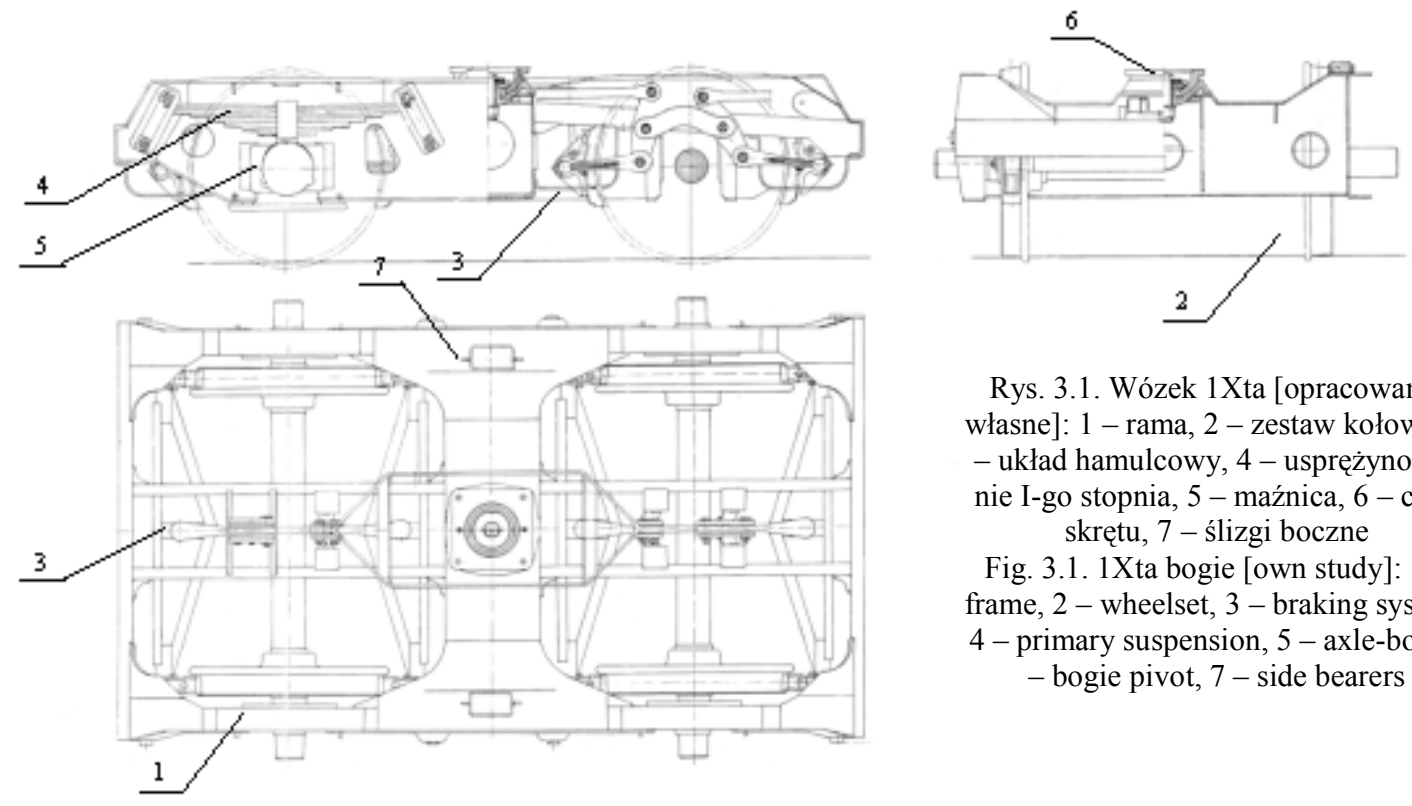

Rys. 3.1. Wózek 1Xta [opracowanie własne]: 1 - rama, 2 - zestaw kołowy, 3 - układ hamulcowy, 4 - usprężynowanie I-go stopnia, 5 - maźnica, 6 - czop skrętu, 7 - ślizgi boczne

Fig. 3.1. 1Xta bogie [own study]: 1 frame, 2 - wheelset, 3 - braking system, 4 - primary suspension, 5 - axle-box, 6

- bogie pivot, 7 - side bearers

Charakterystyka techniczna wózka 1Xta przedstawia się następująco:/ The technical specifications of the 1Xta bogie are as follows:

- szerokość toru (prześwit toru) $[\mathrm{mm}] /$ track gauge (track clearance)

[mm]

- masa $[\mathrm{kg}] /$ weight $[\mathrm{kg}]$

- maksymalna prędkość jazdy $[\mathrm{km} / \mathrm{h}] /$ maximum speed of riding $[\mathrm{km} / \mathrm{h}]$

4750

- ilość osi/ number of axles

- baza wózka $[\mathrm{mm}] /$ bogie base $[\mathrm{mm}]$

- średnica okregu tocznego (koła w stanie nowym/zużytym) [mm]/ diameter of the wheel tread (wheels in new/worn condition) [mm]

- rozstaw środków czopów [mm]/ distance between centres of pivots $[\mathrm{mm}]$

- wymiary czopa osi (średnica x długość) $\mathrm{mm}] /$ dimensions of axle journal (diameter $x$ length) $[\mathrm{mm}]$

$\varnothing 120 \times 179$

- łożyska/ bearings

- typ/ type

NJ+NJP lub WJ+WJP

- wymiary (śr.wew./śr.zew./szer.) [mm]/ dimensions (internal diameter/external diameter/width) [mm]

$120 \times 240 \times 80$

- usprężynowanie/ suspension

- rodzaj/type:

pojedyncze - piórowe/single - leaf

- liczba/number:

- thumienie/damping:

wlasne/own

- miękkość całkowita $[\mathrm{mm} / \mathrm{kN}] /$ total softness $[\mathrm{mm} / \mathrm{kN}]$

$1,65 / 1.65$

- nacisk zestawu kołowego na tor $[\mathrm{t}] /[\mathrm{kN}] /$ wheelset load on the track $[\mathrm{t}] /[\mathrm{kN}] /$

$18 / 176,52 / 18 / 176.52$

- długość całkowita [mm]/ total length [mm]

- szerokość [mm]/ width [mm]

- wysokość od główki szyny [mm]/ height from the rail head [mm]

- luzy w prowadnicach/ clearances in guides

- poprzeczne $[\mathrm{mm}] /$ lateral $[\mathrm{mm}]$

- hamulec/brake 


\subsection{Y25Lsd1-3Tnfa/1 bogie} Y25Lsd 1 - 3Tnfa/1 bogie is presented in fig. 3.2.

\subsection{Wózek Y25Lsd1-3Tnfa/1}

Wózek Y25Lsd1 - 3Tnfa/1 przedstawiono na rys. 3.2.

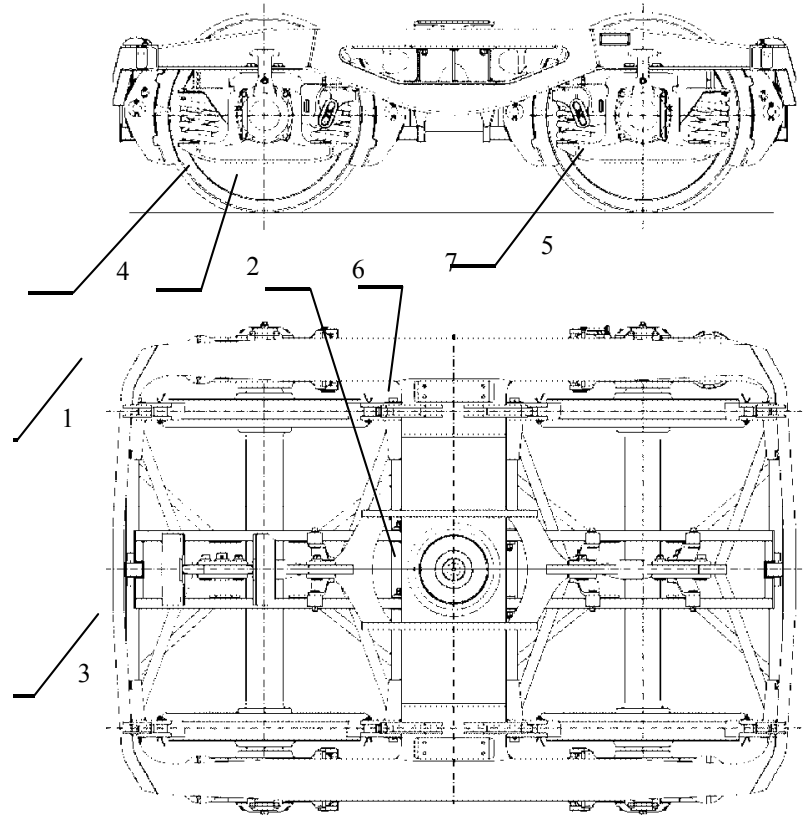

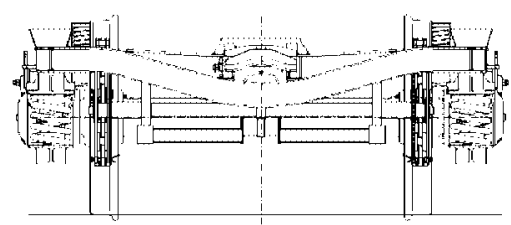

Rys. 3.2. Wózek Y25Lsd1 3Tnfa/1 [Opracowanie własne]: 1 - rama, 2 - zestaw kołowy, 3 układ hamulcowy, 4 usprężynowanie I-go stopnia, 5 - maźnica, 6 - czop skrętu, 7 ślizgi boczne

Fig. 3.2. Y25Lsd $1-3$ Tnfa/1 bogie [own study]: 1 - frame, 2 - wheelset, 3 - braking system, 4 - primary suspension, 5 axle-box, 6 - bogie pivot, 7 side bearers

Charakterystyka techniczna wózka Y251sd1 - 3TNfa/1 przedstawia się następująco:

The technical specifications of the $5 \mathrm{TN}$ bogie are as follows:

- $\quad$ szerokość toru (prześwit toru) $[\mathrm{mm}] /$ track gauge (track clearance) [mm]

- $\quad$ masa $[\mathrm{kg}] /$ weight $[\mathrm{kg}]$

- maksymalna prędkość jazdy [km/h]/ maximum speed of riding $[\mathrm{km} / \mathrm{h}]$

- rozstaw osi zestawów kołowych [mm] (baza wózka)/ distance between the axles of wheesets [mm] (bogie base)

- $\quad$ średnica okręgu tocznego (koła w stanie nowym/zużytym) $[\mathrm{mm}] /$ diameter of the wheel tread (wheels in new/worn condition) [mm]

- rozstawienie ślizgów bocznych [mm]/ distance between the side bearers [mm]

- ilość osi/ number of axles

- rozstaw poprzeczny środków czopów maźnic zestawów kołowych [mm]/ lateral distance between centres of pivots of wheelset axle-boxes [mm]

- usprężynowanie progresywne/ progressive suspension - miękkość usprężynowania [mm/kN]/ softness of suspension [mm/kN]

- gniazdo skrętu kuliste o promieniu [mm]/ spherical bogie pin with radius [mm]

- wysokość środka ,zaczepienia” promienia gniazda skrętu od główki szyny (pod obciążeniem wagonem próżnym o masie własnej 20t) [mm]/ height of the centre of bogie pin radius from the rail head (under the load of an empty wagon with its tare weight of 20t) [mm]

- łożyska/ bearings

- typ:/type:

- wymiary (śr.wew./śr.zew./szer.) [mm]/ dimensions (internal diameter/external diameter/width) [mm]

- maksymalny nacisk zestawu kołowego na tor $[\mathrm{t}] /[\mathrm{kN}] /$ maximum load of wheelset on the track $[\mathrm{t}] /[\mathrm{kN}]$

- wymiar czopa osi (średnica $\mathrm{x}$ długość) $[\mathrm{mm}] /$ dimension of axle journal (diameter $\mathrm{x}$ length) $[\mathrm{mm}]$

- maksymalny przesuw poprzeczny ramy wózka (korpus prowadnicy) względem korpusu maźnicy [mm]/ maximum lateral travel of bogie frame (body of guide) towards the body of axle-box [mm]

- długość wózka [mm]/ bogie length [mm]

- szerokość wózka [mm]/ bogie weight [mm]

- hamulec [-]/brake [-]
100 dla nacisku z.k. na tor $22,5 t / 100$ for load of wheelset on track $22.5 \mathrm{t}$

120 dla nacisku z.k. na tor $14,5 \mathrm{t} /$

120 for load of wheelset on track $14.5 \mathrm{t}$

1800

$\varnothing 920 / \varnothing 870$

1700

$\mathbf{2 , 4 6 2}$ dla nacisku z.k na tor $\mathbf{?} 130,43 \mathrm{kN} / 2.462$ for load of wheelset on track ?130.43 kN 0,938 dla nacisku z.k na tor $>130,43 \mathrm{kN} / 0.938$ for load of wheelset on track $>130,43 \mathrm{kN}$

190

$925^{+3}-5$

walcowe, NJ+NJP lub WJ+WJP/ cylindrical, $\mathbf{N J}+\mathbf{N J P}$ or WJ+WJP

$130 \times 240 \times 80$

$22,5 / 220,65 / 22.5 / 220.65$

Ø130x191 


\section{3. $5 T N / 5 T N / 1$ bogie}

$5 \mathrm{TN}$ bogie is presented in fig. 3.3 .

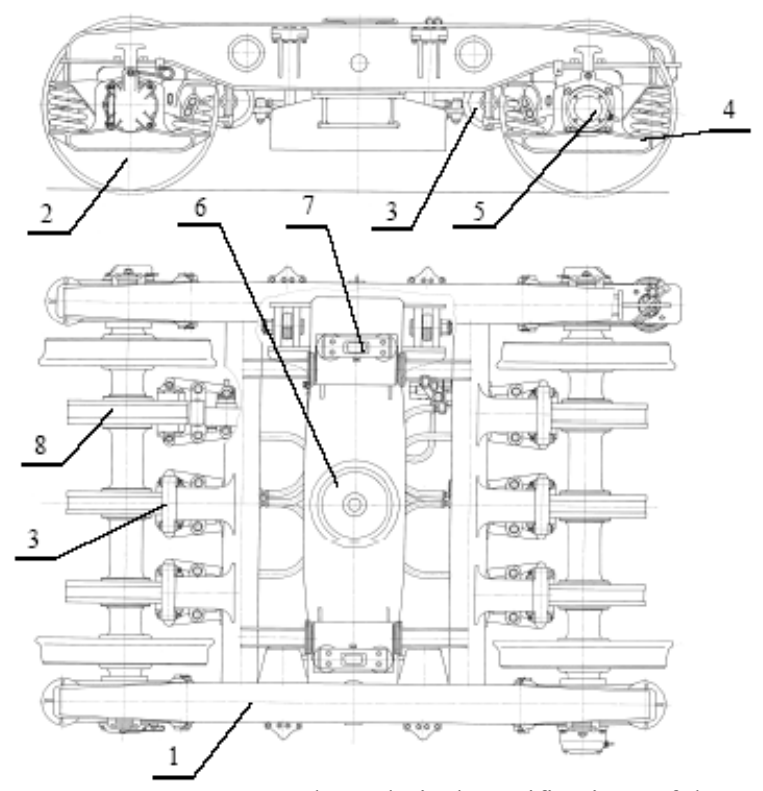

3.3. Wózek 5TN/5TN/1

Wózek 5TN przedstawiono na rys. 3.3.

The technical specifications of the TVP2007 bogie are as follows:

- szerokość toru (prześwit toru) $[\mathrm{mm}] /$ track gauge (track clearance) [mm]

Rys. 3.3. Wózek 5TN [Opracowanie własne]: 1 - rama, 2 - zestaw kołowy, 3 zaciski hamulcowe,

4 - usprężynowanie I-go stopnia, 5 maźnica, 6 - czop skrętu, 7 - ślizgi

boczne, 8 - tarcza hamulcowa

Fig. 3.3. 5TN bogie[Own study]: 1 frame, 2 - wheelset, 3 - brake clamps, 4 - primary suspension, 5 - axle-box, 6 bogie pivot, 7 - side bearers, 8 - brake disc

- masa $[\mathrm{kg}] /$ weight $[\mathrm{kg}]$

- maksymalna prędkość jazdy $[\mathrm{km} / \mathrm{h}] /$ maximum speed of riding $[\mathrm{km} / \mathrm{h}]$

- rozstaw osi zestawów kołowych [mm] (baza wózka)/ distance between the axles of wheesets [mm] (bogie base)

- średnica okręgu tocznego (koła w stanie nowym/zużytym) $[\mathrm{mm}] /$ diameter of the wheel tread (wheels in new/worn condition) [mm]

$\varnothing 840 / \varnothing 770$

- rozstawienie ślizgów bocznych $[\mathrm{mm}] /$ distance between the side bearers $[\mathrm{mm}]$

- ilość osi/ number of axles

- gniazdo skrętu kuliste o promieniu [mm]/ spherical bogie pin with radius [mm]

długość wózka $[\mathrm{m}] /$ length of bogie [m]

- szerokość wózka [m]/ width of bogie [m]

- położenie górnej powierzchni ślizgów bocznych do poziomu główki szyny [mm]/ position of the upper surface of side bearers to the level of the rail head [mm]

- wysokość środka ,zaczepienia” promienia gniazda skrętu od główki szyny (dla wagonu o masie 20t) [mm] (rys.2)/ height of the centre of bogie pin radius from the rail head (for the wagon wagon with weight of $20 \mathrm{t}$ ) [mm] (fig.2)

- łożyska/ bearings

- typ:/type:

- wymiary (śr.wew./śr.zew./szer.) [mm]/ dimensions (internal diameter/external diameter/width) [mm]

- maksymalny nacisk zestawu kołowego na tor $[\mathrm{t}] /[\mathrm{kN}] /$ maximum load of wheelset on the track $[\mathrm{t}] /[\mathrm{kN}]$

- wymiar czopa osi (średnica x długość) $[\mathrm{mm}] /$ dimension of axle journal (diameter $\mathrm{x}$ length) [mm]

- maksymalny przesuw poprzeczny ramy wózka względem korpusu maźnicy [mm]/ maximum lateral travel of bogie frame towards the body of axle-box [mm]

- hamulec *)/ brake*)

- typ/type

- wymiary tarczy (średnica zewnętrzna x szerokość) [mm]/ dimensions of disc (external diameter $\mathrm{x}$ width) $[\mathrm{mm}]$

- przełożenie mechanizmu zaciskowego/ ratio of the clamping mechanism

walcowe, $\mathbf{N J}+\mathbf{N J P}$, WJ+WJP/ cylindrical, NJ+NJP, WJ+WJP

130x240x80

$18 / 176,52 / 18 / 176.52$

Ø130x191

- luz belki bujakowej względem ramy wózka $[\mathrm{mm}] /$ clearance of the bolster beam towards the bogie frame [mm]

$\operatorname{tarczowy} /$ disc

$610 \times 110$

- całkowity luz poprzeczny wózka [mm]/ total lateral clearance of the bogie [mm] 


\subsection{TVP 2007 bogie}

TVP 2007 bogie is presented in fig. 3.4.

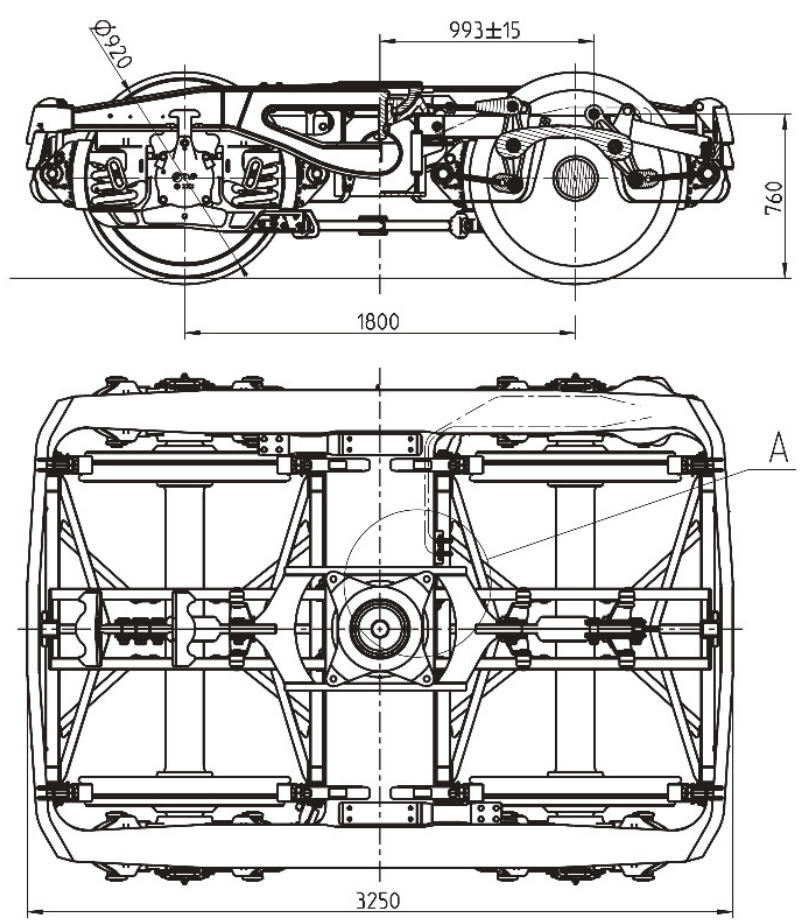

\subsection{Wózek TVP 2007}

Wózek TVP 2007 przedstawiono na rys. 3.4.

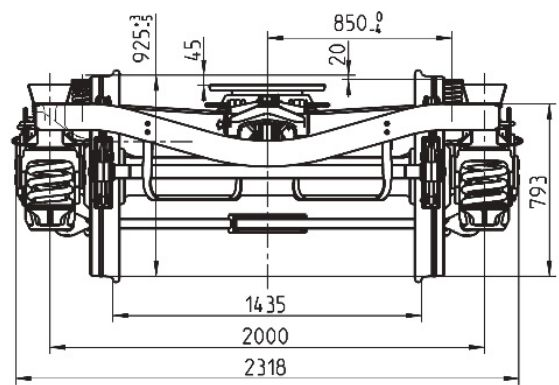

Rys. 3.4. Wózek TVP2007
A $1: 10$

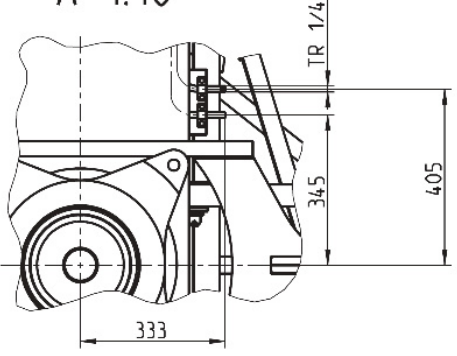

[Opracowanie własne na podstawie [8]]: 1 - rama, 2 zestaw kołowy, 3 - układ hamulcowy, 4 - usprężynowanie I-go stopnia, 5 - maźnica, 6 czop skrętu, 7 - ślizgi boczne Fig. 3.4. TVP2007 bogie [Own study based on [8]]: 1 - frame, 2 - wheelset, 3 - brake system, 4 - primary suspension, 5 - axlebox, 6 - bogie pivot, 7 - side bearers

The technical specifications of the TVP2007 bogie are as follows:

- $\quad$ szerokość toru (prześwit toru) [mm]/ track gauge (track clearance) [mm]

- masa $[\mathrm{kg}] /$ weight $[\mathrm{kg}]$

- maksymalna prędkość jazdy [km/h]/ maximum speed of riding $[\mathrm{km} / \mathrm{h}]$

- rozstaw osi zestawów kołowych [mm] (baza wózka)/ distance between the axles of wheesets [mm] (bogie base)

- $\quad$ średnica okręgu tocznego (koła w stanie nowym/zużytym) [mm]/ diameter of the wheel tread (wheels in new/worn condition) [mm]

- rozstawienie ślizgów bocznych [mm]/ distance between the side bearers [mm]

- ilość osi/ number of axles

- rozstaw poprzeczny maźnic (osi wzdłużnych korpusów) [mm]/ lateral distance of axle - boxes (longitudinal axes of bodies) [mm]

- gniazdo skrętu kuliste o promieniu [mm]/ spherical bogie pin with radius [mm]

- wysokość środka ,zaczepienia” promienia gniazda skrętu od główki szyny (pod obciążeniem wagonem próżnym o masie własnej 20t) (rys.2)/ height of the centre of bogie pin radius from the rail head (under the load of an empty wagon with its tare weight of 20t) (fig.2)

- maksymalny nacisk zestawu kołowego na tor $[\mathrm{t}] /[\mathrm{kN}] /$ maximum load of wheelset on the track $[\mathrm{t}] /[\mathrm{kN}]$

- maksymalny przesuw poprzeczny ramy wózka względem korpusu maźnicy $[\mathrm{mm}] /$ maximum lateral travel of bogie frame towards the body of axle-box $[\mathrm{mm}]$

- długość wózka [mm]/ length of bogie [mm]

- $\quad$ szerokość wózka [mm]/ width of bogie [mm]

- hamulec [-]/brake[-]
1435

4750

120 dla nacisku z.k. na tor $22,5 t / 120$ for load of wheelset on track $22.5 \mathrm{t}$

1800

$\varnothing 920 / \varnothing 870$

1700

2000

190

$925^{+3}-5$

$22,5 / 220,65$ dla $V=120 \mathrm{~km} / \mathrm{h} /$

22.5/220.65 for $V=120 \mathrm{~km} / \mathrm{h}$ 25/245,17 dla $V=100 \mathrm{~km} / \mathrm{h} /$ 25/245.17 for $V=100 \mathrm{~km} / \mathrm{h}$ 


\subsection{TVP NG-DBS bogie}

TVP NG-DBS bogie is presented in fig. 3.5.
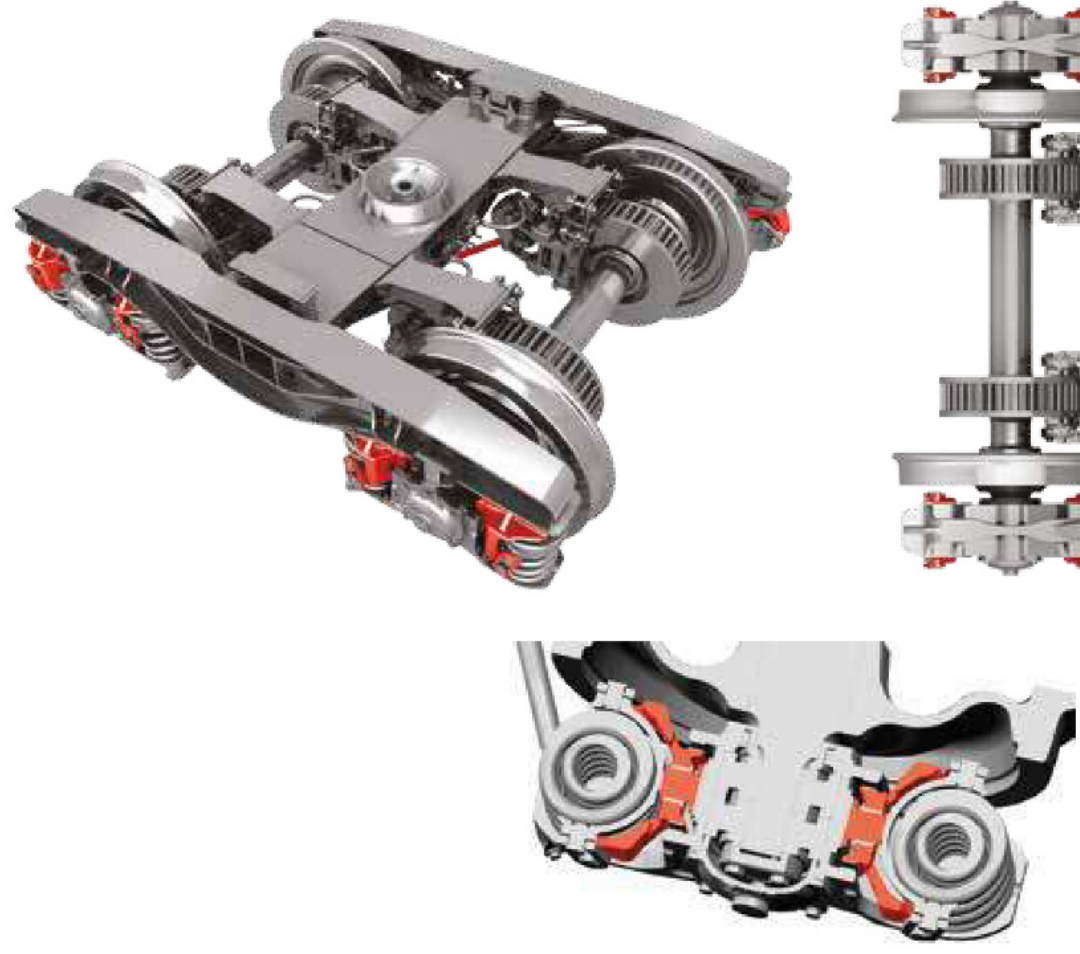

\subsection{TVP NG-DBS bogie}

TVP NG-DBS bogie is presented in fig. 3.5.

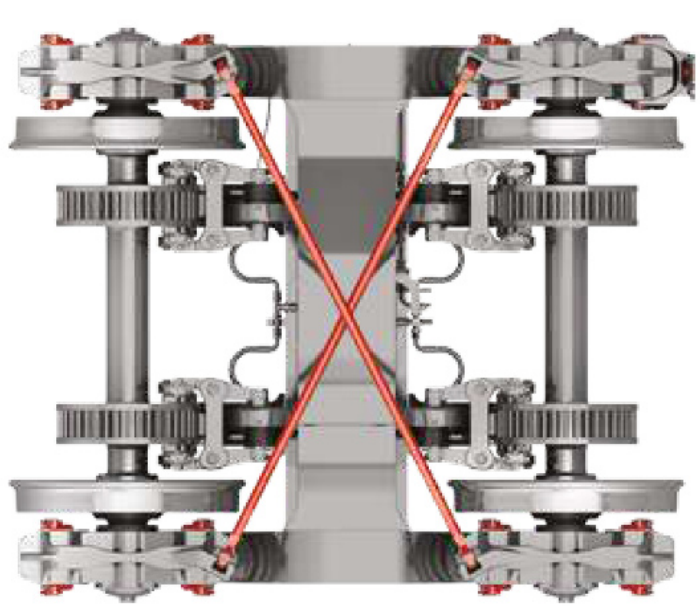

Rys. 3.5. Wózek TVP NG-DBS

[Opracowanie własne na podstawie [8]]: 1 - rama, 2 - zestaw kołowy, 3 - tarcza hamulcowa 4 - usprężynowanie I-go stopnia, 5 - maźnica, 6 - czop skrętu, 7 ślizgi boczne, 8 - mechanizm zaciskowy Fig. 3.5. TVP NG-DBS bogie [Own study based on [8]]: 1 - frame, 2 - wheelset, 3 brake disc 4 - primary suspension, 5 axle-box, 6 - bogie pivot, 7 - side bearers, 8 - clamping mechanism

The technical specifications of the TVP NG-DBS bogie are as follows:

- szerokość toru (prześwit toru) [mm]/ track gauge (track clearance)

[mm]

- masa $[\mathrm{kg}] /$ weight $[\mathrm{kg}]$

- maksymalna prędkość jazdy [km/h]/ maximum speed of riding [km/h]

- rozstaw osi zestawów kołowych [mm] (baza wózka)/ distance between the axles of wheesets [mm] (bogie base)

- średnica okręgu tocznego (koła w stanie nowym/zużytym) [mm]/ diameter of the wheel tread (wheels in new/worn condition) $[\mathrm{mm}]$

- rozstawienie ślizgów bocznych $[\mathrm{mm}] /$ distance between the side bearers $[\mathrm{mm}]$

120 dla nacisku z.k. na tor $22,5 \mathrm{t} /$

120 for load of wheelset on track $22.5 \mathrm{t}$

1800

- ilość osi/ number of axles

- rozstaw poprzeczny maźnic (osi wzdłużnych korpusów) [mm]/ lateral distance of axle - boxes (longitudinal axes of bodies) [mm]

$\varnothing 920 / \varnothing 840$

gniazdo skrętu kuliste o promieniu $[\mathrm{mm}] /$ spherical bogie pin with radius [mm]

- wysokość środka „zaczepienie” promienia gniazda skrętu od główki szyny (pod obciążeniem wagonem próżnym o masie własnej 20t) (rys.2)/ height of the centre of bogie pin radius from the rail head (under the load of an empty wagon with its tare weight of 20t) (fig.2)

- maksymalny nacisk zestawu kołowego na tor $[\mathrm{t}] /[\mathrm{kN}] /$ maximum load of wheelset on the track $[\mathrm{t}] /[\mathrm{kN}]$

- maks. Przesuw poprzeczny ramy wózka względem korpusu maźnicy $[\mathrm{mm}] /$ maximum lateral travel of bogie frame towards the body of axle-box [mm]

- hamulec [-]/brake[-]

1700 


\subsection{TVP Y25Lssi(f)-D bogie}

TVP Y25Lssi(f)-D bogie is presented in fig. 3.6.

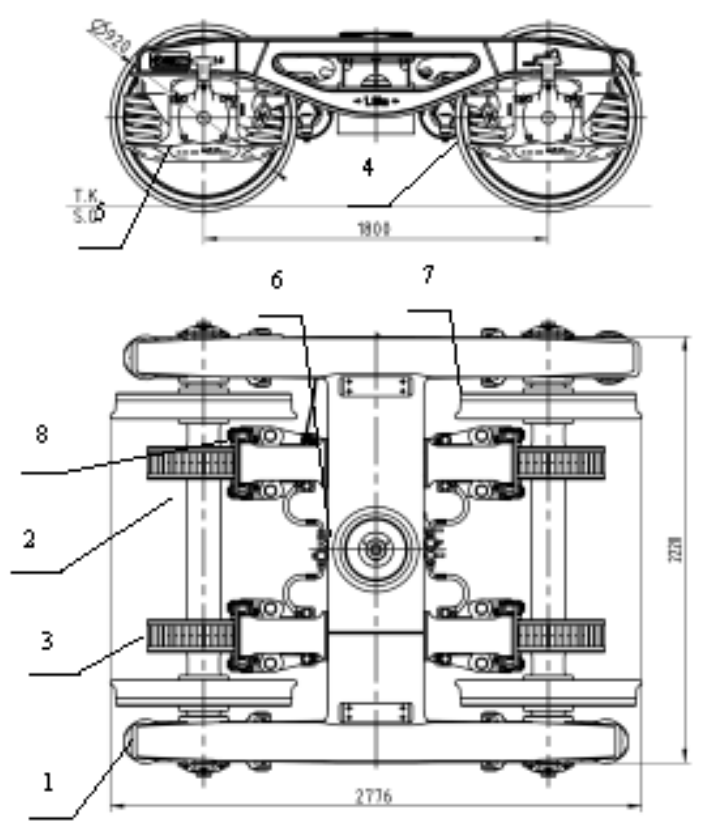

3.6. Wózek TVP Y25Lssi(f)-D

Wózek TVP Y25Lssi(f)-D przedstawiono na rys. 3.6.

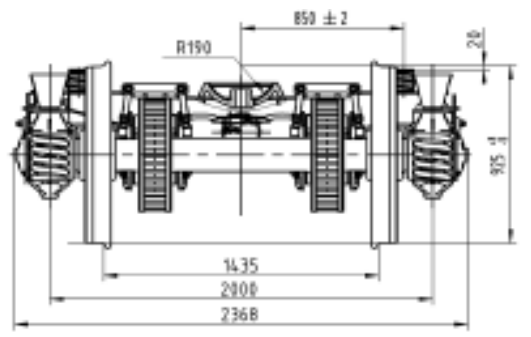

Rys. 3.6. Wózek TVP Y25Lssi(f)-D [Opracowanie własne na podstawie [8]]: 1 - rama, 2 - zestaw kołowy, 3 - tarcza hamulcowa, 4 - usprężynowanie I-go stopnia, 5 - maźnica, 6 - czop skrętu, 7 - ślizgi boczne, 8 - mechanizm zaciskowy

Fig. 3.6. TVP Y25Lssi(f)-D bogie [Own study based on [8]]: 1 - frame, 2 wheelset, 3 - brake disc, 4 - primary suspension, 5 - axle-box, 6 - bogie pivot, 7 - side bearers, 8 - clamping mechanism

The technical specifications of the TVP Y25Lssi(f)-D bogie are as follows:

- szerokość toru (prześwit toru) [mm]/ track gauge (track clearance) [mm]

- masa $[\mathrm{kg}] /$ weight $[\mathrm{kg}]$

- maksymalna prędkość jazdy $[\mathrm{km} / \mathrm{h}] /$ maximum speed of riding $[\mathrm{km} / \mathrm{h}]$

- rozstaw osi zestawów kołowych [mm] (baza wózka)/ distance between the axles of wheesets [mm] (bogie base)

120 dla nacisku z.k. na tor/120 for load of wheelset on track $22.5 \mathrm{t}$

1800

- średnica okręgu tocznego (koła w stanie nowym/zużytym) [mm]/ diameter of the wheel tread (wheels in new/worn condition) [mm]

$0920 / 0840$

- rozstawienie ślizgów bocznych [mm]/ distance between the side bearers [mm]

- ilość osi/ number of axles

- rozstaw poprzeczny maźnic (osi wzdłużnych korpusów maźnic) [mm]/ lateral distance of axle - boxes (longitudinal axes of bodies) [mm]

- gniazdo skrętu kuliste o promieniu [mm]/ spherical bogie pin with radius [mm]

- wysokość środka promienia gniazda skrętu od główki szyny (pod obciążeniem w wagonie próżnym o masie własnej $20 \mathrm{t}$ ) [mm]/ height of the centre of bogie pin radius from the rail head (under the load of an empty wagon with its tare weight of 20t) (fig.2)

- maksymalny nacisk zestawu kołowego na tor $[\mathrm{t}] /[\mathrm{kN}] /$ maximum load of wheelset on the track $[\mathrm{t}] /[\mathrm{kN}]$

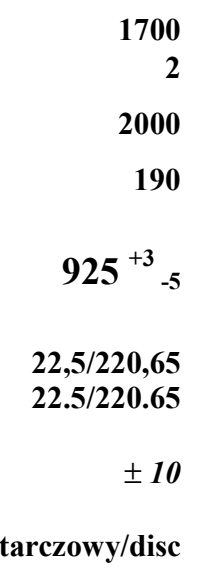

\section{GENERAL REQUIREMENTS WITHIN THE SCOPE OF RUNNING GEARS}

The process of designing the running gear is a complex process depending on the structure of the whole vehicle, performed based on the criteria contained in the relevant normative acts and the technical specification that should include:

- the space required for the whole vehicle (required outline of vehicle), limited with the permissible reference profile of the kinematic gauge

- necessary physical connections i.e. electric and pneumatic

\section{OGÓLNE WYMAGANIA W ZAKRESIE UKŁADÓW BIEGOWYCH}

Proces projektowania układu biegowego jest procesem złożonym, współzależnym od konstrukcji całego pojazdu, wykonywanym w oparciu o kryteria zawarte w odpowiednich aktach normatywnych oraz o specyfikacje techniczną która powinna obejmować:

- wymaganą przestrzeń dla całego pojazdu (wymagany zarys pojazdu), ograniczony z dopuszczalnym zarysem odniesienia skrajni kinematycznej

- niezbędne przyłącza fizyczne tj. elektryczne, pneumatyczne 
- vehicle weight, permissible loading capacity and specified load conditions

- the required operating speed with the appropriate tolerance for the maximum speed for the appropriate limit of tilt deficiency

- body stiffness and/or natural frequencies of vibrations

- brake system interface and performance

- detection of overheated axle - boxes (HABD -ASDEK system) (involves the necessity of providing the access to the bearings and thus requires the use of external bearings)

- other auxiliary systems (e.g. data transmission from the track to the vehicle)

- track characteristics

- maximum load of the wheelset on the track, the limits of dynamic wheel load $\mathrm{Q}_{\max }=\mathrm{Q}_{\text {stat }}+90 \mathrm{kN}$;

- working environment (including environmental conditions)

- work cycles

- permissible noise levels emitted to the natural environment

- permissible values of the level of vibrations emitted to the natural environment.

Moreover, the constructional requirements and dynamic properties should be specified:

- required space for the bogie/running gear

- physical connections for the bogie/running gear

- weight of bogie/running gear components and accessories, etc.;

- payload and loads, including loading/unloading

- elements of the traction system, route characteristics and work cycles, including emergency states

- devices of braking system, characteristics of braking system and work cycles

- mechanical connection of the bogie with the body

- masses and moments of inertia (e.g. body parameters) included in the specification

- other essential characteristics of body (e.g. stiffness/bending moments) influencing on dynamics

- reference outline of the gauge which is the basis for determining the outline of the vehicle so that it does not collide with fixed devices during the most unfavourable operating conditions

- operating conditions and route characteristics

- outer wheel outline (new and worn) and/or limits of conicity if they are specified.
- masę pojazdu, dopuszczalna ładowność oraz określone stany obciążenia

- wymaganą prędkość eksploatacyjną wraz z odpowiednią tolerancją dla prędkości maksymalnej dla odpowiedniej granicy niedoboru przechyłki

- sztywność nadwozia i/lub częstotliwości własne drgań

- interfejs systemu hamulcowego i wydajność

- wykrywanie przegrzanych maźnic (HABD system ASDEK) (wiąże się z koniecznością zapewnienia dostępu do łożysk a tym samym wymusza stosowanie ułożyskowanie zewnętrznego)

- pozostałe systemy pomocnicze (itp. Przesyłanie danych z toru na pojazd)

- charakterystykę toru

- maksymalny nacisk zestawu kołowego na tor, granice dynamicznego obciążenia koła $\mathrm{Q}_{\max }=\mathrm{Q}_{\text {stat }}+90 \mathrm{kN}$;

- środowisko pracy ( $\mathrm{w}$ tym warunki środowiskowe)

- cykle pracy

- dopuszczalne wartości poziomu hałasu emitowanego do środowiska naturalnego

- dopuszczalne wartości poziomu drgań emitowanych do środowiska naturalnego.

Ponadto powinny zostać określone wymagania konstrukcyjne oraz własności dynamiczne:

- wymagana przestrzeń dla wózka/układu biegowego

- przyłącza fizyczne dla wózka/układu biegowego

- masy elementów wózka/układu biegowego oraz osprzętu, itp.;

- ładowność i obciążenia, w tym stany ładowania/wyładowania

- elementy systemu trakcji, charakterystyki trasy oraz cykle pracy w tym stany awaryjne

- urządzenia systemu hamulcowego, charakterystyka systemu hamulcowego oraz cykle pracy

- podłączenie mechaniczne wózka z nadwoziem

- masy i momenty bezwładności (itp. Parametry nadwozia) załączone w specyfikacji

- pozostałe istotne charakterystyki nadwozia (itp. Sztywności/momenty gnące) wpływające na dynamikę

- zarys odniesienia skrajni który jest podstawa do wyznaczenia zarysu pojazdu tak, aby podczas najbardziej niekorzystnych stanów eksploatacyjnych nie wchodził $\mathrm{w}$ kolizję $\mathrm{z}$ urządzeniami stałymi

- warunki pracy i charakterystyki trasy

- zarys zewnętrzny koła (nowego i zużytego) i/lub granice stożkowatości jeśli są określone. 
Among the above-mentioned, one of the most important functional features of the body is the possibility of negotiating the wagon into a curve with a minimum radius of $\mathrm{R} 35 \mathrm{~m}$ or $\mathrm{R} 75 \mathrm{~m}$. These curves are not on the routes, but only make the internal infrastructure of rolling stock repair plants, carriers etc.

The calculations of the maximum angle of rotation of the bogies in relation to the axis of the freight wagon body, while passing through the curve of the track with the minimum radius, were determined on the basis of the methodology presented in the report of ORE/ERRI B12DT135 [1].

The total angle of rotation $\varphi_{3}$ of the bogie in relation to the body consists of two angles of rotation $\varphi_{1}$ and $\varphi_{2}$. The angles $\varphi_{1}$ and $\varphi_{2}$ are presented in fig.4.1 and fig.4.2. Passing through the curve with the minimum radius should be performed using two methods:

- an analytical method based on the methodology presented in the report of ORE/ERRI B12DT135

- an experimental method, through the curve that was recognized as passable for the wagon.

The criterion for the correct test is the lack of collision of bogie parts adjacent to the wagon body parts. Both bogies and the wagon body should be visually inspected.

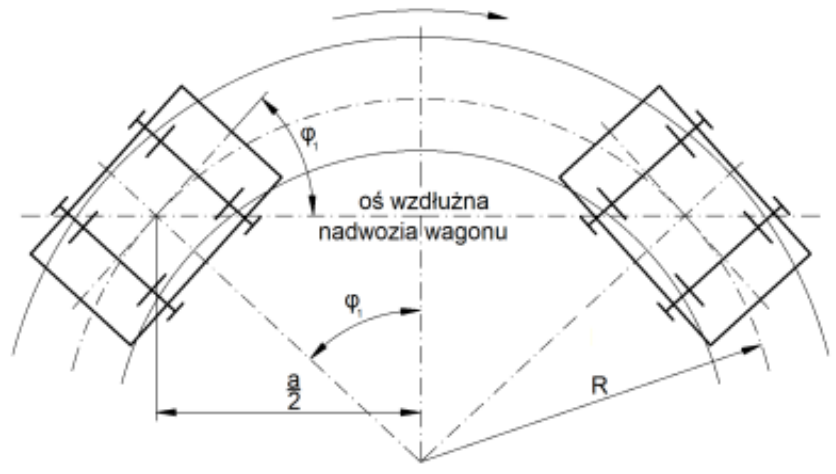

Legenda/legend: oś wzdłużna nadwozia wagonu - longitudinal axis of the wagon body

Rys. 4.1. Kąt $\varphi_{1}$ obrotu wózka względem nadwozia na łuku o promieniu R [1]

Fig. 4.1. The angle $\varphi_{1}$ of bogie rotation relative to the body on the curve with radius $\mathrm{R}[1]$

The total angle of rotation $\psi 3$ is determined from the following relation:

$$
\varphi_{3}=\varphi_{1}+\varphi_{2}
$$

Placing the dependencies resulting from fig.2.16 and fig.2.17 the angle $\psi 3$ is:

$$
\varphi_{3}=\arcsin \frac{a}{2 R}+\arcsin \frac{2\left(\frac{\sigma}{2}+q\right)}{p}
$$

gdzie:/where:

a-odległość pomiędzy czopami skrętów (baza wagonu);/ distance between pivots (wagon base)
Spośród wyżej wymienionych jedną z ważniejszych cech funkcjonalnych wózka jest umożliwienie wpisywania się wagonu w tuk o minimalnym promieniu R35 m lub R75 m. Łuki te nie występują na szlakach ale wyłączenie stanowią infrastrukturę wewnatrzzakładową zakładów naprawczych taboru, przewoźników itp.

Obliczenia maksymalnego kąta obrotu wózków w stosunku do osi nadwozia wagonu towarowego, podczas przejazdu przez łuk toru o minimalnym promieniu, wyznaczono w oparciu o metodykę, przedstawioną w raporcie ORE/ERRI B12DT135 [1].

Całkowity kąt obrotu $\varphi_{3}$ wózka $w$ stosunku do nadwozia składa się z dwóch kątów obrotu $\varphi_{1}$ oraz $\varphi_{2}$. Katy $\varphi_{1}$ oraz $\varphi_{2}$ są przedstawione na rys.4.1 i rys.4.2. Przejazd przez łuk o minimalnym promieniu należy przeprowadzić dwoma metodami:

- metodą analityczną w oparciu o metodykę, przedstawioną w raporcie ORE/ERRI B12DT135

- metodą doświadczalną, przez łuk który został uznany jako przejezdny dla wagonu.

Kryterium prawidłowej próby jest brak kolizji części wózka, sąsiadujących z częściami nadwozia wagonu. Obydwu wózki oraz nadwozie wagonu powinny być poddane obserwacji wizualnej.

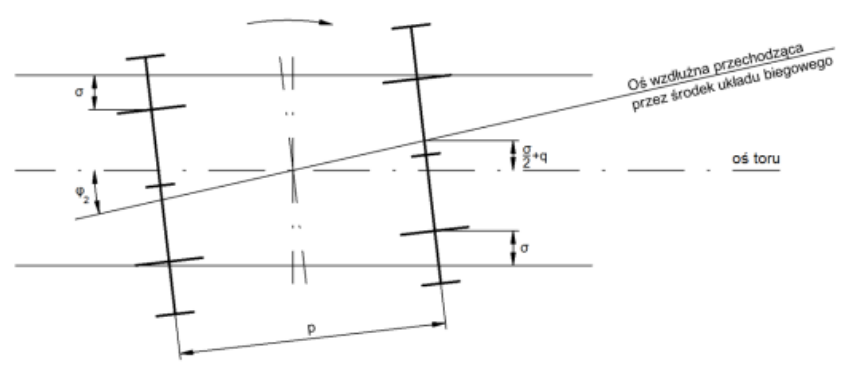

Legenda/legend: oś wzdłużna przechodząca przez środek układu biegowego - longitudinal axis through the center of running gear oś toru -track axis

Rys.4.2.Kąt $\varphi_{2}$ obrotu wózka względem nadwozia na łuku o promieniu R [1]

Fig.4.2. The angle $\varphi_{2}$ of bogie rotation relative to the body on the curve with radius $\mathrm{R}$ [1]

Sumaryczny kąt obrotu $\psi 3$ wyznacza się z następującej zależności:

$$
\varphi_{3}=\varphi_{1}+\varphi_{2}
$$

Podstawiając zależności, wynikające z rys.2.16 oraz rys.2.17 kąt $\psi 3$ wyniesie:

$$
\varphi_{3}=\arcsin \frac{a}{2 R}+\arcsin \frac{2\left(\frac{\sigma}{2}+q\right)}{p}
$$

gdzie:/where:

a-odległość pomiędzy czopami skrętów (baza wagonu);/ distance between pivots (wagon base) 
R- minimalny promień łuku toru, przez który może przejechać wagon czteroosiowy, na wózkach z zawieszeniem typu Y25; $\sigma$ - luz $w$ torze określony przez różnice prześwitów toru oraz szerokości prowadnej zestawu kołowego; przyjmujac maksymalny prześwit toru $1470 \mathrm{~mm}$ oraz minimalna szerokość prowadna zestawu kołowego $1410 \mathrm{~mm}$ otrzymuje się różnice wynoszaca $\sigma=60 \mathrm{~mm}$;/ minimum radius of track curve through which a four-axle wagon can pass on bogies with Y25 type; $\sigma$ clearance in track defined by the difference between the track gauges and the guide width of the wheelset; assuming the maximum track gauge of $1470 \mathrm{~mm}$ and the minimum guide width of the wheelset of $1410 \mathrm{~mm}$ it is obtained the difference of $\sigma=60 \mathrm{~mm}$

p- baza wózka, która wynosi 1,8 m dla wózków typu Y25;// bogie base which is $1.8 \mathrm{~m}$ for bogies of Y25 type

q- luz poprzeczny pomiędzy korpusem maźnicy i korpusem prowadnicy, w przypadku wózków typu $Y 25 \mathrm{luz}$ poprzeczny $q=10 \mathrm{~mm} /$ lateral clearance between the body of axle box and the body of guide, in the case of Y25 bogies the lateral clearance $q=10 \mathrm{~mm}$.

Mając na uwadze powyższe $\mathrm{w}$ tablicy 3 przedstawiono kąty obrotu $\mathrm{j}_{1}, \mathrm{j}_{2}, \mathrm{j}_{3}$ dla wybranych typów wagonów.

Taking into account the above, table 3 presents the angles of rotation $j_{1}, j_{2}, j_{3}$ for the selected types of wagons.

Wykaz kątów obrotu $\varphi_{1}, \varphi_{2}, \varphi_{3}$ dla wybranych typów wagonów dla wartości $\sigma=60 \mathrm{~mm}$ Tablica 3 List of rotation angles $\varphi_{1}, \varphi_{2}, \varphi_{3}$ for the selected types of wagons for value $\sigma=60 \mathrm{~mm}$ Table 3

\begin{tabular}{|c|c|c|c|c|c|c|c|c|}
\hline $\begin{array}{c}\text { Typ } \\
\text { wagonu/Wagon } \\
\text { type } \\
\end{array}$ & $\mathbf{q}[\mathrm{m}]$ & $\mathbf{a}[\mathbf{m}]$ & $\mathbf{p}[\mathbf{m}]$ & $\mathbf{R}[\mathbf{m}]$ & $\sigma[\mathrm{m}]$ & $\varphi_{1}[\mathbf{0}]$ & $\varphi_{2}[\mathbf{0}]$ & $\varphi_{3}[\mathbf{0}]$ \\
\hline $\begin{array}{c}\text { Wagon 60' } \\
\text { Sgnss }\end{array}$ & 0.01 & 14.2 & 1.8 & 75 & 0.06 & 5.43 & 2.54 & 7.97 \\
\hline $\begin{array}{c}\text { Wagon 80' } \\
\text { Sgnss }\end{array}$ & 0.01 & 19.3 & 1.8 & 150 & 0.06 & 3.68 & 2.54 & 6.23 \\
\hline $\begin{array}{c}\text { Wagon 80' } \\
\text { Sgnss }\end{array}$ & 0.01 & 19.3 & 1.8 & 75 & 0.06 & 7.39 & 2.54 & 9.93 \\
\hline Zags 53m3 & 0.01 & 7.45 & $1 ., 8$ & 35 & 0.06 & 6.10 & 2.54 & 8.65 \\
\hline Zags $120 \mathrm{~m} 3$ & 0.01 & 13.5 & 1.8 & 35 & 0.06 & 11.11 & 2.54 & 13.66 \\
\hline Zags 123 m3 & 0.01 & 14.4 & 1.8 & 35 & 0.06 & 11.87 & 2.54 & 14.41 \\
\hline Sns-x & 0.01 & 14.4 & $1 ., 8$ & 75 & 0.06 & 5.50 & 2.54 & 8.05 \\
\hline Rns-z & 0.01 & 16.81 & 1.8 & 75 & 0.06 & 6.43 & 2.54 & 8.98 \\
\hline Shimmns S10B & 0.01 & 7 & 1.8 & 35 & 0.06 & 5.73 & 2.54 & 8.28 \\
\hline $\begin{array}{c}\text { Eamnos 57m3- } \\
\text { E06A }\end{array}$ & 0.01 & 6.5 & 1.8 & 35 & 0.06 & 5.32 & 2.54 & 7.87 \\
\hline $\begin{array}{l}\text { Habbii(II)ns } \\
\quad 352\end{array}$ & 0.01 & 18.36 & 1.8 & 60 & 0.06 & 8.80 & 2.54 & 11.34 \\
\hline
\end{tabular}

However, table 4 presents the rotation angles for the state in which the maximum track gauge is $1435 \mathrm{~mm}$ and the minimum guide width of the wheelset is 1426 $\mathrm{mm}$. Then $\sigma$ takes the value of $9 \mathrm{~mm}$.
W tablicy 4 natomiast przedstawiono kąty obrotu dla stanu, w którym maksymalny prześwit toru wynosi $1435 \mathrm{~mm}$ oraz minimalna szerokość prowadna zestawu kołowego1426 mm. Wówczas $\sigma$ przyjmuje wartość 9 $\mathrm{mm}$. 


\section{Wykaz kątów obrotu $\varphi_{1}, \varphi_{2}, \varphi_{3}$ dla wybranych typów wagonów dla wartości $\sigma=9 \mathrm{~mm} \quad$ Tablica 4 List of rotation angles $\varphi_{1}, \varphi_{2}, \varphi_{3}$ for the selected types of wagons for value $\sigma=9 \mathrm{~mm}$

\begin{tabular}{|c|c|c|c|c|c|c|c|c|}
\hline $\begin{array}{c}\text { Typ } \\
\text { wagonu/Wagon } \\
\text { type } \\
\end{array}$ & $\mathbf{q}[\mathbf{m}]$ & $\mathbf{a}[\mathbf{m}]$ & $\mathbf{p}[\mathbf{m}]$ & $\mathbf{R}[\mathbf{m}]$ & $\sigma[\mathrm{m}]$ & $\varphi_{1}[0]$ & $\varphi_{2}[\mathbf{0}]$ & $\varphi_{3}[\mathbf{0}]$ \\
\hline $\begin{array}{l}\text { Wagon 60' } \\
\text { Sgnss }\end{array}$ & 0.01 & 14.2 & 1.8 & 75 & 0.009 & 5.43 & 0.92 & 6.35 \\
\hline $\begin{array}{c}\text { Wagon 80' } \\
\text { Sgnss }\end{array}$ & 0.01 & 19.3 & 1.8 & 150 & 0.009 & 3.68 & 0.92 & 4.61 \\
\hline $\begin{array}{l}\text { Wagon 80' } \\
\text { Sgnss }\end{array}$ & 0.01 & 19.3 & 1.8 & 75 & 0.009 & 7.39 & 0.92 & 8.31 \\
\hline Zags 53m3 & 0.01 & 7.45 & 1.8 & 35 & 0.009 & 6.10 & 0.92 & 7.03 \\
\hline Zags $120 \mathrm{~m} 3$ & 0.01 & 13.5 & 1.8 & 35 & 0.009 & 11.11 & 0.92 & 12.04 \\
\hline Zags $123 \mathrm{~m} 3$ & 0.01 & 14.4 & 1.8 & 35 & 0.009 & 11.87 & 0.92 & 12.79 \\
\hline Sns-x & 0.01 & 14.4 & 1.8 & 75 & 0.009 & 5.50 & 0.92 & 6.43 \\
\hline Rns-z & 0.01 & 16.81 & 1.8 & 75 & 0.009 & 6.43 & 0.92 & 7.35 \\
\hline Shimmns S10B & 0.01 & 7 & 1.8 & 35 & 0.009 & 5.73 & 0.92 & 6.66 \\
\hline $\begin{array}{c}\text { Eamnos 57m3- } \\
\text { E06A }\end{array}$ & 0.01 & 6.5 & 1.8 & 35 & 0.009 & 5.32 & 0.92 & 6.25 \\
\hline $\begin{array}{c}\text { Habbii(II)ns } \\
352\end{array}$ & 0.01 & 18.36 & 1.8 & 60 & 0.009 & 8.80 & 0.92 & 9.72 \\
\hline
\end{tabular}

Taking into account the above, if there is the necessity of modernization, optimization of construction or design of a completely new vehicle/running gear system, then there is a possibility to contact the Siec Badawcza Łukasiewicz to discuss the specific solutions.

"If the entrepreneur is looking for a complementary service he can also challenge us via the form available at www.lukasiewicz.gov.pl. Model of "challenging” has been in the Eukasiewicz since 15 October 2020 and owing to that we can present the entrepreneur in just 15 days an idea for solving his technological problem. Potential of the Łukasiewicz focuses on such research areas as: health, intelligent mobility, digital transformation, and sustainable economy and energy. Łukasiewicz - IPS "TABOR" belongs to two research areas, one of them is sustainable economy and energy, whose main areas of activity are focused on bioeconomy and material recovery, that is the main components so-called Circular Economy. Another area is the intelligent mobility, the activity of which is focused on the technologies related to the design, formation, production, characterization and using the logistics infrastructure and vehicles."
Mając na uwadze powyższe, w przypadku gdy istnieje konieczność modernizacji, optymalizacji konstrukcji lub projektu zupełnie nowego pojaz-du/układu biegowego wówczas istnieje możliwość zgłoszenia się do Sieci Badawczej Łukasiewicz celem omówienia konkretnych rozwiązań.

„Jeśli przedsiębiorca szuka komplementarnej usługi może nam również rzucić wyzwanie za pośrednictwem formularza znajdującego się na stronie www.lukasiewicz.gov.pl. Model „rzucania wyzwań” funkcjonuje w Łukasiewiczu od 15 listopada 2020 r. i dzięki niemu możemy przedstawić przedsiębiorcy w zaledwie $15 \mathrm{dni}$ pomysł na rozwiązanie jego problemu technologicznego. Potencjał Łukasiewicza skupia się wokół takich obszarów badawczych jak: zdrowie, inteligentna mobilność, transformacja cyfrowa oraz zrównoważona gospodarka i energia. Łukasiewicz - IPS „TABOR” należy do dwóch obszarów badawczych jednym z nich jest zrównoważona gospodarka i energia, którego główne obszary działalności skupiają się wokół biogospodarki i odzysku materiałowego, czyli głównych komponentów tzw. Gospodarki Obiegu Zamkniętego. Kolejnym obszarem jest inteligenta mobilność, której działalność koncentruje się wokół technologii związanych $\mathrm{z}$ projektowaniem, wytwarzaniem, produkcja, charakteryzacją i użytkowaniem infrastruktury logistycznej i pojazdów." 


\section{SUMMARY}

The modern running gear of freight wagon should be characterized by:

- low tare weight which makes it possible to increase the loading weight of the wagon

- low manufacturing costs

- low operating costs (service life of wearing parts)

- low negative impact on the natural environment (optimization of components influencing on the noise and minimization of wearing parts)

- high structural strength from the point of view of increasing the loads of the wheelsets on the track.

The above parameters force the manufacturers of rolling stock and construction offices to modernize the existing design solutions of running gear or to develop the new constructions that enable the optimization of the structure of freight wagons by increasing the permissible load capacity of the wagon (by increasing the permissible loads of wheelsets on the track) and/or increasing the permissible transport speed.

\section{BIBLIOGRAPHY / BIBLIOGRAFIA}

\section{PODSUMOWANIE}

Nowoczesny układ biegowy wagonu towarowego powinien charakteryzować się:

- niską masą własną, umożliwiającą zwiększenie masy ładunkowej wagonu

- niskimi kosztami wytwarzania

- niskimi kosztami eksploatacji (trwałość elementów ulegającym zużyciu)

- niskim negatywnym oddziaływaniem na środowisko naturalne (optymalizacja elementów wpływających na hałas oraz minimalizacja części podlegających zużyciu)

- wysoką wytrzymałością konstrukcji z punktu widzenia zwiększenia nacisków zestawów kołowych na tor.

Powyższe parametry wymuszają na producentach taboru i biurach konstrukcyjnych konieczność modernizacji istniejących rozwiązań konstrukcyjnych układów biegowych lub opracowanie nowych konstrukcji, które umożliwią optymalizację konstrukcji wagonów towarowych poprzez zwiększenie dopuszczalnej ładowności wagonu ( $\mathrm{w}$ wyniku zwiększenia dopuszczalnych nacisków zestawów kołowych na tor) i/lub zwiększenie dopuszczalnej prędkości przewozowej.

Sobaś M., Zawieszenia i układy biegowe wagonów towarowych, Wydawnictwo IPS „Tabor” Poznań

[2] Terczyński P., Atlas wagonów towarowych, Wydawnictwo Kolpress, Poznań 2011

[3] P.Michalak, W. Jakuszko Innowacyjna uniwersalna lokomotywa dwunapędowa, Zeszyty Naukowo Techniczne SITK RP, Oddziat w Krakowie nr 2 (2019)

[4] Karta UIC 500: Normalizacja taboru transportowego i jego elementów. Zasady, procedury, wyniki.

Wydanie 2 z grudnia 2000

[5] Karta UIC 510-1: Wagony towarowe, uktady biegowe - Normalizacja. Wydanie 9 z 01.01 .78

[6] EN 1527: Kolejnictwo - Wymagania dla wózków i układów biegowych

[7] www.paulus.net.pl-dostęp 08.08.2021

[8] https://tatravagonka.sk - dostęp 08.08.2021

[9] www.wikipedia.org dostęp 08.08.2021 